\title{
Medical Liability in Switzerland
}

Corinne Widmer Lüchinger

\section{General Questions}

\section{A. The Health Care System Framework}

\section{General Introduction}

\section{The health care system in overview}

Under the Swiss Federal Constitution, both the Cantons (Kantone/Cantons/ 1 Cantoni) and the Federal State (Bund/Confédération/Confederazione) are committed to ensuring that all persons are secured against the economic risks of sickness and accidents. ${ }^{1}$ An important role in this respect is played by the different branches of social insurance, in particular by social health insurance, ${ }^{2}$ social accident insurance ${ }^{3}$ and invalidity insurance. ${ }^{4}$

The costs of medical care in Switzerland are covered by social health insurance (Krankenversicherung/assurance-maladie/assicurazione malattie) and, to a lesser extent, by social accident insurance (Unfallversicherung/assuranceaccidents/assicurazione contro gli infortuni) and invalidity insurance (Invalidenversicherung/assurance-invalidité/assicurazione per l'invalidità). ${ }^{5}$

Social health insurance is, as a rule, compulsory for all individuals dom- 3 iciled in Switzerland, regardless of nationality, age, occupation, sex, or

1 Art 41(2) of the Swiss Constitution (Bundesverfassung der Schweizerischen Eidgenossenschaft) of 18 April 1999, SR 101. The official German, French and Italian language versions of Swiss Federal Acts are available online at $<\mathrm{http}: / / \mathrm{www}$. admin.ch/ch/d/sr/sr.html $>$.

2 See infra, nos $10 \mathrm{ff}$.

3 See infra, nos $18 \mathrm{ff}$.

4 See infra, nos $22 \mathrm{f}$.

5 See A Maurer/G Scartazzini/M Hürzeler, Bundessozialversicherungsrecht (3rd edn 2009) $\mathbb{S} 12$ no 42 ff; T Gächter/I Vollenweider, Gesundheitsrecht (2nd edn 2010) paras 829 ff, 840 ff. 
financial means. ${ }^{6}$ However, as the term 'insurance' implies, social health insurance does not actually provide health care, but only bears the costs for (certain) health care services required by the insured. Switzerland does not have a national health care provider. Rather, health care is provided by public and private hospitals, by doctors or other health care professionals. Persons wishing to benefit from social health insurance are generally free to choose their own health care provider. ${ }^{7}$

4 As a rule, compulsory social health insurance only covers the costs for medical care in case of illness. ${ }^{8}$ It does not provide any entitlement to pensions (Rente/rentes/rendite) or daily benefits (Taggeld/indemnités journalières/indennità giornaliere). ${ }^{9}$ However, if a person's capacity to work is reduced due to a health impairment, entitlements to daily benefits or pensions may arise under other branches of Swiss social security law, in particular under the laws of social accident insurance and invalidity insurance.

5 Entitlements under social accident insurance law only arise in cases of 'accidents' (ie a sudden, involuntary injury caused by an extraordinary and extraneous event), not, however, in cases of mere 'illness', except if the illness is work-related. ${ }^{10}$ If a patient is harmed by a medical procedure, it is therefore of central importance whether the medical procedure can be classified as an 'accident', a question which is often hotly debated. ${ }^{11}$ Social accident insurance law is compulsory for persons who are employed in Switzerland, although it is also available on a voluntary basis for selfemployed individuals. ${ }^{12}$

6 Art 3(1) of the Federal Health Insurance Act (HIA) (Bundesgesetz über die Krankenversicherung [KVG]) of 18 March 1994, SR 832.10.

7 See infra, no 13.

8 See infra, no 10.

9 However, the Federal Health Insurance Act (fn 6) does provide for an optional daily benefit insurance (art $67 \mathrm{HIA}$ ); see U Kieser, Schweizerisches Sozialversicherungsrecht (2008) 278 f; Maurer/Scartazzini/Hürzeler (fn 5) $\$ 15 a$.

10 Art 6(1) of the Federal Accident Insurance Act (AIA) (Bundesgesetz über die Unfallversicherung [UVG]) of 20 March 1981, SR 832.20, in conjunction with art 4 of the Federal Act on the General Principles of Social Security Law (GPSS) (Bundesgesetz über den Allgemeinen Teil des Sozialversicherungsrechts [ATSG]) of 6 October 2000, SR 830.1. See generally Kieser (fn 9) $155 \mathrm{f}$.

11 See A Largier, Schädigende medizinische Behandlung als Unfall (2002) passim; Maurer/ Scartazzini/Hürzeler (fn 5) $\$ 16$ no 71; for an overview of the decisions of the Swiss Federal Court, see A Rumo-Jungo, Bundesgesetz über die Unfallversicherung (3rd edn 2003) 23$25,30,33 \mathrm{f}$. Cf also infra, no 26.

12 See arts $1 \mathrm{a}$ and 4 AIA (fn 10). 
Entitlements under invalidity insurance law may arise in cases of 'invalid- $\mathbf{6}$ ity', ie in cases of reduction or loss of earning capacity due to a health impairment. ${ }^{13}$ The cause of invalidity (ie accident, sickness or birth defect) is irrelevant. Like social health insurance, invalidity insurance is compulsory for all individuals domiciled in Switzerland. ${ }^{14}$

In principle, the availability of insurance coverage has no impact on the legal relationship between the patient and the health care provider. ${ }^{15}$ Rather, it is the law under which the health care provider is organised which is, as a rule, decisive. Thus, if the health care provider is a private person, eg a private practitioner or a private hospital, the relationship between the patient and the health care provider will be governed first and foremost by federal private law. In contrast, if the health care provider is a public hospital, the relationship with the patient will generally be governed by cantonal public law. ${ }^{16}$

In medical malpractice cases, the distinction between private federal law and cantonal public law can become relevant in several ways. ${ }^{17}$ Firstly, requirements for liability and statutes of limitation under cantonal public law may differ from those under federal private law. Secondly, cantonal public law may exclude the liability of certain persons, in particular by providing that claims may only be brought directly against the Canton, not, however, against the responsible individual. Thirdly, courts with jurisdiction to hear cases governed by federal private law do not necessarily have jurisdiction over cases governed by cantonal public law. And finally, different procedural rules may apply. Thus, each of the 26 Swiss cantons has its own distinct laws governing public procedure, whereas civil procedure is governed by the new Federal Act on Civil Procedure, which entered into force on 1 January 2011.18

13 See Maurer/Scartazzini/Hürzeler (fn 5) $\mathbb{S} 12$ no $15 \mathrm{ff}$.

14 And also for other persons; see art $1 \mathrm{~b}$ of the Federal Invalidity Insurance Act (IIA) (Bundesgesetz über die Invalidenversicherung [IVG]) of 19 June 1959, SR 831.20, in conjunction with arts $1 \mathrm{a}$ and 2 of the Federal Old-Age and Survivors' Insurance Act (Bundesgesetz ïber die Alters- und Hinterlassenenversicherung [AHVG]) of 20 December 1946, SR 831.10.

15 See also infra, nos 24 and 81.

16 See infra, nos 45 and $95 \mathrm{ff}$.

17 See infra, nos $95 \mathrm{ff}$.

18 Federal Act on Civil Procedure (Schweizerische Zivilprozessordnung [ZPO]) of 19 December 2008, SR 272. See also infra, no 103. 


\section{Social Welfare Provision}

\section{The role of public health care}

9 As pointed out above, ${ }^{19}$ Switzerland does not have a national health care provider. However, several different branches of social insurance play an important role in public health care. These are, in particular, social health insurance, ${ }^{20}$ social accident insurance ${ }^{21}$ and invalidity insurance. ${ }^{22}$

10 Social health insurance covers the costs of medical care in case of illness and is, as a rule, compulsory for all individuals domiciled in Switzerland. 23 Pensions or daily benefits are not available under compulsory social health insurance. ${ }^{24}$ Compulsory social health insurance only provides coverage in case of illness; in contrast, accidents are not covered. An exception is made for accidents which are not covered by accident insurance. ${ }^{25}$ Insurance premiums are owed and paid for by the insured individuals.

11 Although Swiss social health insurance is a state responsibility, there is no monopoly with regard to its administration. ${ }^{26}$ Thus, social health insurance can generally be administered by health insurance funds (Krankenkassen/caisses-maladie/casse malati) organised under private or public law, or by private insurance companies subject to insurance control, ${ }^{27}$ on condition that they have been approved by the federal administration. ${ }^{28}$ There is no statutory restriction on the admitted number of insurers. ${ }^{29}$ Insured persons are free to choose and change their social health insurer provided they observe the statutory termination periods. 30

12 Social health insurance coverage is not automatic; rather, each person domiciled in Switzerland is under a statutory obligation to take out social

19 Supra, no 3.

20 See infra, nos $10 \mathrm{ff}$.

21 See infra, nos $18 \mathrm{ff}$.

22 See infra, nos $22 \mathrm{f}$. On the coordination of the different branches of social security, see Kieser (fn 9) $351 \mathrm{ff}$.

23 See supra, no 3.

24 On the optional daily benefit scheme, see fn 9.

25 Art 1(2)(b) HIA (fn 6).

26 See Gächter/Vollenweider (fn 5) para 689.

27 Federal Insurance Control Act (Bundesgesetz betreffend die Aufsicht über Versicherungsunternehmen [Versicherungsaufsichtsgesetz, VAG]) of 17 December 2004, SR 961.01.

28 See arts 11-13 HIA (fn 6).

29 See Gächter/Vollenweider (fn 5) para 690. Regularly updated official lists of admitted social health insurers are available online, see <http://www.bag.admin.ch/themen/krankenversicherung/00295/index.html?lang=de $>$ (12.01.11).

30 Arts 4(1), 7(1) and (2) HIA (fn 6). 
health insurance within three months. ${ }^{31}$ Social health insurers are not allowed to refuse any person applying for insurance within their local area of activity. 32

In general, insured persons wishing to benefit from social health insurance coverage are free to choose any health care provider admitted under Swiss social health insurance law, ${ }^{33}$ although they may agree to restrict this freedom of choice in order to benefit from lower insurance premiums. ${ }^{34}$

The requirements for admission as a health care provider under Swiss social health insurance law vary. In principle, medical doctors with a federal (or equivalent) diploma and certificate of advanced vocational training are automatically admitted as health care providers under Swiss law. ${ }^{35}$ In consequence, social health insurers cannot choose which private practitioners they (do not) wish to cooperate with, but must bear the costs regardless, as long as the medical service itself is covered by social health insurance.

In contrast, hospitals must be formally admitted if their services are to be paid for by social health insurance. Besides having to meet general requirements regarding infrastructure, personnel and medical attendance, hospitals must correspond to an actual medical 'need' of the population. ${ }^{36}$ Only services provided by those hospitals which are included in the so-called 'hospital list' (Spitalliste) of a Swiss Canton are covered by social health insurance. ${ }^{37}$ However, if the statutory requirements are met, both

31 See art 3(1) HIA (fn 6).

32 Art 4(2) HIA (fn 6).

33 Art 41(1), (1 ${ }^{\text {bis})}$ and (1ter) HIA (fn 6). On the different categories of admitted health care providers, see Maurer/Scartazzini/Hürzeler (fn 5) $\$ 15$ nos $152 \mathrm{ff}$.

34 Arts 41(4) and 62 HIA (fn 6).

35 Art 36 HIA (fn 6); arts 38, 39 of the Federal Health Insurance Regulation (HIR) (Verordnung über die Krankenversicherung [KVV]) of 27 June 1995, SR 832.102. See T Poledna, Arzt und Krankenversicherung, in: MW Kuhn/T Poledna (eds), Arztrecht in der Praxis (2nd edn 2007) 393, $395 \mathrm{f}$. With a view to preventing further increases in social health insurance premiums, a maximum cap on admitting new private practitioners was introduced as a temporary (and highly controversial) federal measure in 2002. Its validity was recently extended for certain categories of private practitioners and doctors in ambulatory medical care institutions (until 31 December 2011). See art 55a(1)(d) HIA (fn 6 ) in conjunction with arts 1 and 1 a of the Federal Regulation on the Restriction of the Admission of Health Care Providers under Compulsory Social Health Insurance (Verordnung über die Einschränkung der Zulassung von Leistungserbringern zur Tätigkeit zu Lasten der obligatorischen Krankenpflegeversicherung [VEZL]) of 3 July 2002, SR 832.103.

36 Art 39(1) HIA (fn 6).

37 Art 39(1)(e) HIA (fn 6). 
public and private hospitals can be admitted as health care providers for the purposes of social health insurance.

16 Not all medical services are covered by social health insurance, although coverage is very broad. In general terms, social health insurance covers the costs for all medical services which aim to diagnose or treat an illness (or, by way of exception, an accident) 38 and its consequences, such as physical examinations, treatment or patient care by doctors, and hospitalisation in the general ward of admitted hospitals. ${ }^{39}$ Maternity-related medical services are also covered. ${ }^{40}$ All medical services must satisfy the requirements of efficacy, utility and cost effectiveness. ${ }^{41}$

17 If coverage is available under social health insurance, health care providers must charge their patients on the basis of standard rates (Tarife/tarifs/ tariffe). ${ }^{42}$ Standard rates are generally agreed on between doctors' professional associations on the one hand and social health insurers on the other; such agreements (Tarifvertrag/convention tarifaire/convenzione tariffale) require approval by the authorities. ${ }^{43}$ All standard agreements regarding ambulant medical services are based on a nationwide framework agreement $^{44}$ (TARMED) ${ }^{45}$ approved by the Federal Council (Bundesrat/Conseil fédéral/Consiglio federale).

18 If an individual is insured under social accident insurance law, the costs of medical care in case of an accident (as opposed to mere illness) will not be covered by social health insurance, but by social accident insurance. 46 Insurance covers both work-related and non-work-related accidents, and also work-related illnesses. 47 If a person's capacity to work is reduced, social accident insurance law also provides entitlements to pensions or

38 See supra, no 10.

39 See art 25 HIA (fn 6).

40 See art 29 HIA (fn 6).

41 Art 32 HIA (fn 6). See A Büchler/T Gächter, Medical Law: Switzerland, in: H Nys (ed), Medical Law, International Encyclopedia of Laws (2010) paras $133 \mathrm{ff}$.

42 Art 44(1) HIA (fn 6). For details, see Maurer/Scartazzini/Hürzeler (fn 5) $\$ 15$ no 182 ff; Poledna (fn 35) 393, $408 \mathrm{ff}$.

43 Art 46(4) HIA (fn 6).

44 Art 43(5) HIA (fn 6).

45 See Poledna (fn 35) 393, $408 \mathrm{ff}$; for the current versions of TARMED, see <http:// www.tarmedsuisse.ch> (12.01.11).

46 See supra, nos 5 and 10.

47 Art 6(1) AIA (fn 10); Maurer/Scartazzini/Hürzeler (fn 5) $\$ 16$ no 51 ff. Part-time employees are only insured against the risk of non-work-related accidents if they are employed for more than eight hours per week by any one employer; see art 7(2) AIA (fn 10) in conjunction with art 13 of the Federal Accident Insurance Regulation (AIR) (Verordnung über die Unfallversicherung [UVV]) of 20 December 1982, SR 832.202. 
daily benefits. Persons for whom social accident insurance law is compulsory, ie employees, must be insured through their employers. Insurance premiums for work-related accidents and illnesses are paid for by the employers, whereas insurance premiums for non-work-related accidents are paid for by the insured. 48

For approximately a third of all employees, ${ }^{49}$ compulsory social accident insurance is administered through the Swiss Accident Insurance Fund (SUVA), an independent, non-profit company organised under federal public law. ${ }^{50}$ Other employees may be insured with either a private insurance company subject to insurance control, or an accident insurance fund organised under public law, or an approved health insurance fund, although in the latter case, pension entitlements are not insured..$^{51}$ There is no statutory restriction on the admitted number of insurers. ${ }^{52}$ Except for those categories of employees for whom insurance with SUVA is compulsory, employers are generally free to choose the social accident insurer for their employees. ${ }^{53}$

In principle, insured persons wishing to benefit from social accident insurance coverage are free to choose any health care provider recognised under social accident insurance law. ${ }^{54}$ Doctors with a federal (or equivalent) diploma are automatically recognised as health care providers. ${ }^{55}$ However, social accident insurers may limit the patients' freedom of choice by entering into nation-wide cooperation agreements with health care providers and entrusting such providers exclusively with the medical treatment of the insured.56 Stationary institutions, such as hospitals and convalescent homes, must meet certain statutory requirements ${ }^{57}$ and also be party to a cooperation agreement with an insurer. ${ }^{58}$

48 Art 91 AIA (fn 10).

49 Maurer/Scartazzini/Hürzeler (fn 5) $\mathbb{\$} 16$ no 14.

50 Art 61 AIA (fn 10).

51 Art 70(2) AIA (fn 10); see Maurer/Scartazzini/Hürzeler (fn 5) $\$ 16$ no 16.

52 Gächter/Vollenweider (fn 5) para 725. Regularly updated official lists of admitted social accident insurers are available online; see $<\mathrm{http}$ ://www.bag.admin.ch/themen/versicher ung/00321/index.html?lang=de $>$ (12.01.11).

53 Art 69 AIA (fn 10).

54 Art 10(2) AIA (fn 10).

55 Art 53(1) AIA (fn 10).

56 Art 56 AIA (fn 10) in conjunction with art 70(1) AIR (fn 47). See Gächter/Vollenweider (fn 5) para 732.

57 See art 68(1) and (2) AIR (fn 47).

58 See arts 15 and 68(3) AIR (fn 47). 
21 Social accident insurance coverage for medical services is generally the same as under social health insurance. ${ }^{59}$ In particular, medical services must satisfy the requirements of efficacy, utility and cost effectiveness. 60 Unlike social health insurance, however, social accident insurance law also provides entitlements to pensions or daily benefits. ${ }^{61}$

22 In case of invalidity, 62 costs for certain types of medical care for insured persons up to the age of 20 are covered by invalidity insurance, which is compulsory for all individuals domiciled in Switzerland.63 However, except in case of birth defects, only costs for medical care aimed directly at integrating the patient into the work (or similar) environment are covered.64 Other entitlements may also arise, such as to daily benefits or pensions. ${ }^{65}$ Invalidity insurance is administered by cantonal public invalidity insurance funds (IV-Stelle/Offices AI/Uffici AI) together with the institutions that administer Old-Age and Survivors' Insurance (AHV/AVS/ AVS). 66

23 In principle, insured persons wishing to benefit from social invalidity insurance coverage are free to choose any health care provider recognised under Swiss social invalidity insurance law. ${ }^{67}$ Doctors with a federal (or equivalent) diploma are automatically recognised as health care providers. 68

24 As pointed out above, 69 the availability of social insurance coverage generally has no effect on the legal relationship between patient and health care provider..$^{70}$ If the health care provider is, eg a private practitioner or a private hospital, the patient will receive medical treatment by way of an individual contract with the practitioner or hospital. ${ }^{71}$ In contrast, if the health care provider is a public hospital, cantonal public law will deter-

59 See Maurer/Scartazzini/Hürzeler (fn 5) $\mathbb{S} 16$ no 98.

60 See arts 10(1) and 54 AIA (fn 10); BGE 123 V 53, 59 (Federal Court decision of 20 February 1997); Gächter/Vollenweider (fn 5) paras 727 ff. Published and, from 2000 onwards, also unpublished Federal Court decisions are available at <http:/ www.bger.ch>.

61 Cf Kieser (fn 9) 279 ff, 337 ff; Maurer/Scartazzini/Hürzeler (fn 5) \$ 16 no 113 ff, 116 ff.

62 On the meaning of invalidity, see supra, no 6.

63 See supra, no 6.

64 Art 12(1) IIA (fn 14); see Maurer/Scartazzini/Hürzeler (fn 5) $\$ 12$ no 42 ff.

65 Cf Kieser (fn 9) 276 ff, 328 ff; Maurer/Scartazzini/Hürzeler (fn 5) $\$ 12$ no 30 ff.

66 On the organisation of Swiss invalidity insurance, see Maurer/Scartazzini/Hürzeler (fn 5) $\int 12$ no 3 ff.

67 Arts 26 ff IIA (fn 14); Maurer/Scartazzini/Hürzeler (fn 5) $\$ 12$ no 79.

68 Art 26(1), (2) IIA (fn 14).

69 Supra, no 7.

70 See also infra, no 81.

71 See infra, nos 77 ff; see also infra, no 45. 
mine the nature of the legal relationship between hospital and patient. ${ }^{72}$ Both under social health, accident and invalidity insurance, patients are generally free to choose their health care provider. ${ }^{73}$ Accordingly, it is their choice, rather than the question of insurance coverage, which will influence whether potential damages claims for medical malpractice will be subject to private or public law. However, it has been suggested that cantonal public law should also apply where patients are treated in a private hospital, insofar as such treatment is covered by social health insurance. ${ }^{74}$

\section{Differences in treating patient's claims}

If a patient is harmed during the course of medical treatment provided by a private practitioner or hospital, his claims for compensation, if any, will be directed against the health care provider itself and/or (where applicable) its employees. ${ }^{75}$ If the patient was treated in a public hospital, cantonal law may provide that claims shall be brought exclusively against the Canton where such hospital is located. ${ }^{76}$ In both instances it is in principle irrelevant whether the harmful medical treatment was (wholly or partially) covered by social health insurance or not. Social health insurance coverage has no impact on the liability of the health care provider. The same applies if the medical treatment in question was covered by social accident insurance 77 or invalidity insurance. However, social security coverage does have an impact on the amount of damages owed directly to the patient by the liable health care provider, as the insurers' contributions will be deducted from the patient's damages claim. ${ }^{78}$

With respect to a patient's social security claims it is in principle irrelevant 26 whether the medical procedure which harmed the patient was already covered by social insurance. However, an exception applies to social accident insurance claims. As pointed out above, social accident insurance

72 See infra, nos $95 \mathrm{ff}$; see also infra, no 45.

73 See supra, nos 13, 20, 23.

74 See T Eichenberger, Arzt am Spital, in: Kuhn/Poledna (fn 35) 351, 353; P Jäger/A Schweiter, Rechtsprechung des Bundesgerichts zum Arzthaftpflicht- und Arztstrafrecht (2nd edn 2006) 19.

76 See infra, nos $95 \mathrm{ff}$.

77 See TA Bühlmann, Die rechtliche Stellung der Medizinalpersonen im Bundesgesetz über die Unfallversicherung vom 20. März 1981 (1985) 155 f, 196 f. 
claims only arise in case of an 'accident'.$^{79}$ If, however, a patient is harmed during medical treatment for an injury which in itself constitutes an 'accident' (eg during medical treatment for an injury suffered in a car accident), such harm will be sufficient to give rise to social accident insurance claims. It will not be necessary for the harmful event to also qualify as an 'accident'. 80

\section{Right of recourse}

27 To the extent that a patient who has suffered harm in the course of medical treatment is legally entitled to contributions from social health, accident or invalidity insurers, such insurers subrogate in all claims of the insured and the insured's survivors against those providing the treatment, regardless of the basis of such claims (ie tort or contract). ${ }^{81}$ Subrogation takes place at the moment of the event. ${ }^{82}$

28 This right of recourse is also exercised in practice primarily by those insurers whose contributions are long-term, such as social accident insurance and, in particular, invalidity insurance. Both the Swiss Accident Insurance Fund (SUVA) 83 and the Federal Social Insurance Office (FSIO) operate a division dedicated solely to recourse against liable third parties. ${ }^{84}$ In the case of medical malpractice, the practice of SUVA is to exercise its right of recourse if its own doctors consider the case to be clear-cut. SUVA will then endeavour to reach an agreement with the health care provider's liability insurer, if necessary based on an expert opinion jointly commissioned by both insurers. ${ }^{85}$ In practice, however, subrogation by invalidity insurance is more important, and in case of

79 See supra, no 5.

80 Art 6(3) AIA (fn 10); art 10 AIR (fn 47). See, eg, BGE 128 V 169, 171 (Federal Court decision of 2 May 2002).

81 Art 72 GPSS (fn 10).

82 See U Kieser, ATSG-Kommentar (2nd edn 2009) art 72 para 12.

83 See supra, no 19.

84 Cf art 14 of the Federal Regulation on the General Principles of Social Security Law (Verordnung über den Allgemeinen Teil des Sozialversicherungsrechts [ATSV]) of 11 September 2002, SR 830.11. See also the official site of the FSIO, <http://www.regress.admin.ch/ regress/organisation/d/index.htm $>(12.01 .11)$.

85 Information obtained with thanks from lic.iur. Sylvia Läubli Ziegler, head of the recourse division of SUVA, in January 2010. 
dispute, such claims are also brought before court. ${ }^{86}$ Social health insurers only rarely exercise their right of recourse. ${ }^{87}$

As pointed out above, 88 any social insurance contributions to which the patient is entitled will be deducted from any claim brought by the patient against the liable party. ${ }^{89}$ However, the insured patient is entitled to the so-called preferential quota of damages (Quotenvorrecht/droit préférentiel/ diritto preferenziale). .90

\section{Private Insurance}

\section{The role of private health insurance}

In addition to compulsory social health insurance, persons may take out supplementary private health insurance (Zusatzversicherungen/assurances complémentaires/assicurazioni complementari). Private health insurance complements social health insurance in that it offers benefits beyond those provided under social health insurance, for example by granting access to the private or semi-private ward of a hospital. For persons unable to benefit from social accident insurance law or wishing to take out complementary accident insurance, private accident insurance is also available. ${ }^{91}$

Contracts for private health or accident insurance are governed primarily by private law. 92 The contents of such contracts can be determined more or less freely by the insured and the insurer; in the case of private health insurance, relatively few restrictions apply. .3

To the extent that a patient who has suffered harm in the course of medical treatment has actually received indemnification from his private

86 For a recent example, see BGE 134 III 636 (Federal Court decision of 23 September 2008).

87 See $O$ Guillod, Compensation in the Swiss Health Care Sector, in: J Dute/MG Faure/H Koziol (eds), No-Fault Compensation in the Health Care Sector (2004) 392, 411 (at no 78).

88 Supra, no 25.

89 Art 73(3) GPSS (fn 10).

90 Art 73 GPSS (fn 10). See Kieser (fn 82) art 73 paras 1 ff; G Frésard-Fellay, Le recours subrogatoire de l'assurance-accidents sociale contre le tiers responsable ou son assureur (2007) paras $968 \mathrm{ff}$.

91 See Maurer/Scartazzini/Hürzeler (fn 5) $\$ 16$ no 94; R Nebel, in: H Honsell (ed), Bundesgesetz über den Versicherungsvertrag (VVG) (2001) art 101 no 54.

92 In particular by the Federal Act on Insurance Contracts (AIC) (Bundesgesetz über den Versicherungsvertrag [Versicherungsvertragsgesetz, VVG]) of 2 April 1908, SR 221.229.1.

93 See Maurer/Scartazzini/Hürzeler (fn 5) $\$ 15$ no $217 \mathrm{ff}$. 
health or accident insurer, ${ }^{94}$ such insurer subrogates in the claims of the insured against the person providing the treatment. ${ }^{95}$ However, under federal insurance contract law, subrogation only takes place with respect to claims in tort, as opposed to claims in contract. ${ }^{96}$ Moreover, subrogation under federal insurance contract law requires that the tortfeasor acted intentionally or negligently; strict liability is not sufficient. ${ }^{97}$ If the third party is liable only in contract, it is controversial whether a private insurer may nonetheless take recourse against such party based on the general provisions of the Code of Obligations. ${ }^{98}$ In any case, the insured patient is entitled to the preferential quota of damages. ${ }^{99}$

\section{Liability insurance}

33 Where a patient alleges medical malpractice, claims will often be considered by the health care provider's liability insurer before the claim is brought before a court. Until September 2007, liability insurance for medical activities was only compulsory under federal law in a few specific areas. ${ }^{100}$ Outside these areas, it was for the Cantons to decide whether to introduce compulsory liability insurance for medical practitioners. However, the new Federal Act on Academic Medical Professions now provides that all persons who practice an academic medical profession independently must take out professional liability insurance or provide other, equivalent security, regardless of the type of medical activity involved. ${ }^{101}$

34 Whether or not health care providers which fall outside the scope of this Act (such as hospitals, academic medical professionals conducting their

94 Contrast art 72 GPSS (fn 10), pursuant to which the mere fact of entitlement already triggers subrogation by social insurers; see supra, no 27.

95 Art 72(1) AIC (fn 92).

96 Art 72(1) AIC (fn 92). See AK Schnyder in: H Honsell et al (eds), Basler Kommentar: Obligationenrecht I (art 1-529 OR) (4th edn 2007) art 51 no 22; C Graber in: Honsell (fn 91) Art 72 no 7.

97 BGE 120 II 191, 196 (Federal Court decision of 23 June 1994); R Brehm, Berner Kommentar zum schweizerischen Privatrecht, Bd VI, 1. Abt, 3. Teilbd, 1. Unterteilbd: Kommentar zu Art 41-61 OR (1998) art 51 no 61; Schnyder (fn 96) art 51 no 22; Graber (fn 96) art 72 no 7, 9; H Hausheer, Unsorgfältige ärztliche Behandlung, in: P Münch/T Geiser (eds), Schaden - Haftung - Versicherung (1999) para 15.124.

98 Namely arts 50 and 51 of the Code of Obligations (CO) (Bundesgesetz betreffend die Ergänzung des Schweizerischen Zivilgesetzbuches [Fünfter Teil: Obligationenrecht]) of 30 March 1911, SR 220; see Brehm (fn 97) art 51 no 111 ff; Graber (fn 96) art 72 no 8.

99 Cf Hausheer (fn 97) para 15.124; Graber (fn 96) art 72 no 36 ff. Cf also supra, no 29.

100 See infra, no 34.

101 Art 40 lit $\mathrm{h}$ of the Federal Act on Academic Medical Professions (AAMP) (Bundesgesetz über die universitären Medizinalberufe [MedBG]) of 23 June 2006, SR 811.11. 
practice in the form of a company by whom they are employed, or nonacademic medical professionals) must take out professional liability insurance remains a matter for cantonal law, 102 except with respect to a few specific areas as mentioned above. Thus, liability insurance must be taken out under federal law where ionizing radiation or radioactive substances are applied to the human body. ${ }^{103}$ Where clinical drug trials are conducted on humans, the person or institution managing or financing the trial must take out liability insurance or provide other, equivalent security. ${ }^{104}$ Liability insurance for an amount of CHF 20 million or equivalent security is also required for xenotransplantation procedures. ${ }^{105}$

According to a report of the Federal Health Office from the year 2005,106 the following annual liability insurance premiums can be considered typical for doctors practicing in Switzerland (calculated on the basis of an insured amount of CHF 5 million and a franchise of CHF 200):107

- general medicine: approx CHF 1,000;

- surgery (excluding cosmetic and plastic surgery): approx CHF 6,500;

- internal medicine, including gastroenterology and endoscopy: approx CHF 4,000;

- otorhinolaryngology: approx CHF 6,500;

102 C Müller, Medizinische Berufshaftpflichtversicherung, Aktuelle Juristische Praxis (AJP) 2007, 329, 336; see generally W Fellmann, in: A Ayer/U Kieser/T Poledna/D Sprumont (eds), Medizinalberufegesetz (MedBG): Kommentar (2009) art 40 no $16 \mathrm{f}$.

103 Art 28 in conjunction with art 31 lit d of the Federal Act on Radioprotection (Strahlenschutzgesetz [StSG]) of 22 March 1991, SR 814.50.

104 Art 54(1)(b) of the Federal Act on Drugs and Medical Products (DMPA) (Bundesgesetz über Arzneimittel und Medizinprodukte [Heilmittelgesetz, HMG]) of 15 December 2000, SR 812.21, in conjunction with art 7(2) of the Federal Regulation on Clinical Trials with Drugs and Medical Products (CTR) (Verordnung über klinische Versuche mit Heilmitteln [VKlin]) of 17 October 2001, SR 812.214.2.

105 Art 46 lit a of the Federal Act on Transplantation of Organs, Tissue and Cells (TA) (Bundesgesetz über die Transplantation von Organen, Geweben und Zellen [Transplantationsgesetz]) of 8 October 2004, SR 810.21, in conjunction with art 26(1), (2) of the Federal Regulation on Transplantation of Animal Organs, Tissue and Cells (Verordnung über die Transplantation von tierischen Organen, Geweben und Zellen [Xenotransplantationsverordnung]) of 16 March 2007, SR 810.213.

106 Bundesamt für Gesundheit (BAG), Bericht zu Handen der SGK-S, Auftrag SGK-N vom 28.4.2005: Abklärungen zum Obligatorium der Berufshaftpflichtversicherung/Berufshaftpflicht der Ärztinnen und Ärzte, accessible at <http://www.bag.admin.ch/themen/ berufe/00993/01238/01268/index.html> (12.01.11); see also Müller, AJP 2007, 329, 333.

107 On the liability insurance market in Switzerland, see also M Pergolis, Die Haftpflichtversicherung für Ärzte und Spitäler, in: W Fellmann/T Poledna (eds), Die Haftung des Arztes und des Spitals (2003) 167 ff; Guillod (fn 87) 392, $410 \mathrm{f}$ (at para 74). 
- urology: approx CHF 6,000;

- paediatrics: approx CHF 1,200;

- plastic surgery (pure cosmetic surgery): approx CHF 20,000-60,000.

36 According to unofficial estimates, the total amount of insurance premiums paid by all Swiss public hospitals lies somewhere between CHF 50-100 million per year. ${ }^{108}$

\section{Professional Standards}

\section{Applicable professional standards}

37 All persons practicing an academic medical profession independently must comply with the general professional rules set out in federal law. In particular, such persons are required to 'practice their profession carefully and conscientiously and to respect the limits of the skills acquired through university education, postgraduate training and advanced vocational training. ${ }^{109}$ Violations of these rules may entail disciplinary sanctions. ${ }^{110}$ More specific rules are set out in federal acts relating to particularly sensitive areas, such as organ transplantation. ${ }^{111}$ Professional rules for those health care providers to whom federal law does not apply, ${ }^{112}$ remain a matter of cantonal law. ${ }^{113}$

38 Members of the Swiss Medical Association (FMH) are also subject to the association's rules of professional conduct (Standesordnung/Code de déontologie/ codice deontologico), 114 which provide that doctors must practice their profession 'carefully and conscientiously'. ${ }^{115}$ A violation of these rules can be

108 PJ Meier/M Klee, Ärztehaftpflicht: Versicherer sahnen ab, Beobachter 24/2008.

109 Art 40 lit a AAMP (fn 101).

110 Art 43 AAMP (fn 101). See M Marti/P Straub, Arzt und Berufsrecht, in: Kuhn/Poledna (fn 35) $233,258 \mathrm{f}$.

111 See art 4 TA (fn 105), pursuant to which persons handling organs, tissue or cells are required to take all measures necessary according to the latest findings of science and technology in order to prevent health risks. See also W Fellmann, Arzt und das Rechtsverhältnis zum Patienten, in: Kuhn/Poledna (fn 35) 103, 124 ff.

112 See MedBG/Fellmann (fn 102) art 40 no $15 \mathrm{ff}$.

113 See, eg, $\mathbb{S} 19(1)$ of the Health Act of the Canton of Zurich (Gesundheitsgesetz) of 2 April 2007, accessible at <http://www.zhlex.zh.ch $>$ (12.01.11).

114 Available at <http://www.fmh.ch/fmh/rechtliche_grundlagen/standesordnung.html> (12.01.11).

115 Art 3(1) (fn 114). 
sanctioned by the FMH professional conduct committee. However, as the FMH is a private organisation, its rules are only binding on its members.

The various guidelines of the Swiss Academy of Medical Sciences, 116 such as guidelines on reanimation, palliative care or coercive measures, also lack binding authority as the Academy does not have law-making power. ${ }^{117}$

Where a patient has suffered harm in the course of medical treatment, the test applied by the courts is generally whether the doctor acted lege artis, ie in accordance with the 'generally recognised rules of the medical profession'.118 The nature and scope of these 'generally recognised rules' are determined in the instant case on the basis of expert advice. ${ }^{119}$ According to the Federal Court, the requirements 'cannot be fixed once and for all. Rather, they depend on the particularities of the instant case, such as the nature of the intervention or the treatment and the associated risks, the scope for discretion, the time and means available, and the training and capacity of the doctor.' 120

Violations of the leges artis constitute a breach of contract and, if the further requirements are met, may lead to contractual liability for pecuniary and non-pecuniary loss. ${ }^{121}$ In tort, a violation of the leges artis may lead to unlawfulness. ${ }^{122}$ Moreover, both in contract and in tort claims, the act of departing from professional standards constitutes fault. ${ }^{123}$

\section{Quality and/or risk management systems}

The Federal Council has the power to introduce systematic quality controls with regard to those medical services which are covered by social health insurance. It may entrust professional or other associations with these controls. ${ }^{124}$

To date, the Federal Council has merely introduced a legal obligation on all health care providers admitted under social health insurance law (or

116 See <http://www.samw.ch $>$ (12.01.11).

117 Cf D Rüetschi, Die Medizinisch-ethischen Richtlinien der SAMW aus juristischer Sicht, Schweizerische Ärztezeitung (SÄZ) No 23/2004, 1222 ff.

118 See, eg, BGE 133 III 121, 124 (Federal Court decision of 9 February 2007).

119 See Fellmann (fn 111) 103, $120 \mathrm{ff}$.

120 See, eg, BGE 133 III 121, 124 (Federal Court decision of 9 February 2007).

121 Cf infra, nos 82 and 86.

122 See infra, nos $51 \mathrm{f}$. For an overview of the decisions of the Swiss Federal Court relating to doctors' professional standards, see Jäger/Schweiter (fn 74) $31 \mathrm{ff}, 37 \mathrm{ff}$.

123 Cf Guillod (fn 87) 392, 394 (at para 8).

124 Art 58(1) and (2) HIA (fn 6). 
their professional associations) to develop concepts of, and programmes on, quality standards and quality advancement. ${ }^{125}$ However, the modalities of quality control and the consequences of failure to comply with quality standards are not set out in federal law; rather, these must be developed and agreed on by health care providers and insurers (or their respective associations). Currently, there are no such agreements in place. ${ }^{126}$ However, several hospitals and managed care networks of general practitioners have introduced quality management systems on a voluntary basis, or are considering doing so. ${ }^{127}$

44 As far as risk management is concerned, health care professionals are under an obligation to inform the authorities in certain statutorily defined situations, in particular in case of uncertain cause of death. ${ }^{128}$ However, there is no legal obligation to introduce actual risk management systems. Nonetheless, several hospitals have introduced such systems on a voluntary basis. 129

\section{B. Tort Liability}

\section{Fundamentals of tort liability}

45 In the context of medical malpractice in Switzerland, it is essential to distinguish between liability under federal private law on the one hand, and liability under cantonal public law on the other. In general, federal private law will apply if the health care provider is a private person (eg a private hospital or a private practitioner). However, there are exceptions. Thus, where a Canton has delegated the exercise of State power (imperium) to a private hospital, the relationship between patient and hospital may be subject to cantonal public law. ${ }^{130}$ Moreover, where a public hospital has been privatised, the majority opinion in Switzerland is that the liability of

125 Art 77 HIR (fn 35).

126 See Maurer/Scartazzini/Hürzeler (fn 5) $\$ 15$ no 210.

127 Cf, eg, the website of the EQUAM association: <http://www.equam.org> (12.01.11).

128 For an overview, see U Zollinger/K Hartmann, Ärztliche Melderechte und Meldepflichten gegenüber Justiz und Polizei, SÄZ No 26/2001, 1384 ff.

129 On the current situation with regard to clinical risk management systems, see M Briner et al, Erste Schweizer Erhebung zum klinischen Risikomanagement im Spital, SÄZ No 15-16/2009, 635 ff. Several hospitals have also introduced Critical Incident Reporting Systems (CIRS); see U Haller et al, Von der Schuldfrage zur Fehlerkultur in der Medizin, SÄZ No 27/2005, $1665 \mathrm{ff}$; H Kuhn, It is forbidden to crash this airplane, in: Fellmann/Poledna (fn 107) 181, 210, 211.

See the references to case law in Jäger/Schweiter (fn 74) $20 \mathrm{ff}$. 
such hospital will remain subject to cantonal public law. ${ }^{131}$ It is controversial whether a private hospital's liability should also be subject to cantonal public law where a patient's treatment is covered by social health insurance. ${ }^{132}$ Finally, where the liability of public hospital doctors toward their private patients is concerned, the Cantons are free to preempt federal private law. 133

The following paragraphs on tort liability are confined to liability under federal private law. Liability under cantonal public law will be discussed separately, ${ }^{134}$ as will liability in contract. 135

Under the general clause of art 41(1) of the Code of Obligations (CO),136 four requirements must be met for liability in tort. Firstly, a person must have suffered damage, ie a pecuniary loss (Schaden/dommage/danno). Secondly, such damage must be wrongful (widerrechtlich/illicite/illecito). Thirdly, there must be a causal link between the wrongful conduct and the damage suffered, ie the conduct must be a conditio sine qua non of the damage suffered (so-called 'natural causation'; natürliche Kausalität/causalité naturelle/causalità naturale), and such damage must not be too remote (so-called 'adequate causation'; adäquate Kausalität/causalité adéquate/causalità adeguata). Finally, it is required that the tortfeasor was at fault, ie that he was of sufficient mental capacity (Urteilsfühigkeit/capacité de discernement/ capacità di discernimento) and that he acted either intentionally or negligently. ${ }^{137}$ It is undisputed in today's case law that a doctor is liable for any fault, regardless of the degree. 138

A person may also be held responsible for the wrongful conduct of third parties under art 55(1) CO (vicarious liability). Other than the general requirements of damage, wrongfulness and causation, liability under art 55(1) CO requires that the person who actually caused the damage (the 'servant') must be subordinated to the party who is to be held liable (the

131 See J Gross, Haftung des Spitalarztes und des Spitals, in: Fellmann/Poledna (fn 107) 35, $44 \mathrm{f} ;$ Fellmann (fn 111) 103, $109 \mathrm{f}$. On the liability of privatised hospitals, see generally M Hofer/S Schmid-Geene, Die Haftung privatisierter Spitäler - ein Überblick, Haftung und Versicherung (HAVE) 2002, $196 \mathrm{ff}$.

132 See supra, no 24 and the references in fn 74 .

133 See infra, nos 80 and 97 and the references in fn 280 .

134 See infra, nos $95 \mathrm{ff}$.

135 See infra, nos $77 \mathrm{ff}$.

136 See fn 98.

137 See H Rey, Ausservertragliches Haftpflichtrecht (4th edn 2008) paras 805 ff, 834 ff; Brehm (fn 97) art 41 no $1 \mathrm{ff}$.

138 See, eg, BGE 133 III 121, 124 (Federal Court decision of 9 February 2007); BGE 113 II 429, $432 \mathrm{f}$ (Federal Court decision of 3 November 1987); Guillod (fn 87) 392, $394 \mathrm{f} \mathrm{(at}$ para 11). For an overview of the development in case law, see $i d(\mathrm{fn} 87$ ) at paras $8 \mathrm{ff}$. 
'master'). A person is 'subordinated' for the purposes of art 55(1) CO if he is subject to another's supervision and authority to issue directives. ${ }^{139}$ The legal nature of the relationship between 'master' and 'servant' is irrelevant. Rather, it is the de facto subordination of one person to another which is decisive. ${ }^{140}$ Both natural persons (eg a private practitioner) and legal persons (eg a hospital with independent legal personality) can be 'master' for the purposes of art 55(1) CO.

49 Liability under art 55(1) CO also requires that the damage must have been caused in the course of the subordinated person's work or duties (in Ausübung der geschäftlichen oder dienstlichen Verrichtung/dans l'accomplissement de son travail/nell'esercizio delle incombenze di servizio o d'affari). A merely accidental connection to the subordinated person's work or duties will not suffice. ${ }^{141}$

50 A party may avoid liability under art 55(1) CO by proving that he took all precautions necessary to prevent damage of the kind suffered, namely that he exercised all due diligence in selecting, instructing and overseeing the 'servant' (curae in eligendo, instruendo et custodiendo), and also that all work processes were organised diligently. If this proof fails, he may still avoid liability if he can show that damage would have occurred even if all due diligence had been exercised. ${ }^{142}$

51 In the context of medical malpractice, particular importance lies with the requirement of wrongfulness under art 41(1) and art 55(1) CO. Under the majority opinion, each and any interference with a person's physical integrity constitutes wrongfulness for the purposes of tort law, unless the tortfeasor can invoke grounds for justification. The Swiss Federal Court has constantly held that this also applies in the medical context, so that prima facie, any interference with a patient's physical integrity constitutes wrongfulness, even if the intervention was made by a doctor with the purpose of healing the patient, and even if there was no mistake in treatment. ${ }^{143}$ The doctor can avoid liability by showing that such intervention was justified, in particular by proving that the patient gave his

139 See, eg, Brehm (fn 97) art 55 no 7 ff, 11 ff; Rey (fn 137) paras 903 ff.

140 See, eg, Rey (fn 137) para 904; Brehm (fn 97) art 55 no 7.

141 See, eg, Rey (fn 137) paras $912 \mathrm{ff}$.

142 See generally Brehm (fn 97) art 55 no 45 ff. On liability for organisational deficiencies, see infra, nos $61 \mathrm{f}$.

143 See, eg, BGE 108 II 59, 62 (Federal Court decision of 12 January 1982); unpublished Federal Court decision 4C.378/1999 of 23 November 2004, at para 3.1; for further references, see Jäger/Schweiter (fn 74) 65 ff. For a critique of this development, see $V$ Roberto, Schweizerisches Haftpflichtrecht (2002) paras 93 ff. 
informed consent. ${ }^{144}$ If he succeeds in proving this, the intervention will only be considered wrongful if the patient can show that the intervention was not lege artis, which is often very difficult to prove.

If a medical intervention which interferes with a patient's physical integ- 52 rity is not lege artis, the requirement of wrongfulness will always be met. Informed consent does not cover mistakes in treatment. ${ }^{145}$

A characteristic of Swiss tort law is its comparatively short statute of limitations. The general limitation period for pecuniary and non-pecuniary loss claims in tort is one year from the day that the harmed person acquired knowledge of the damage and the liable party's identity. In any event, the maximum limitation period is ten years from the day of the harmful conduct. 146 The short one-year period is one of the reasons why claimants generally prefer to sue in contract rather than in tort. 147 The extension of the general limitation period for tort claims is currently on the political agenda. ${ }^{148}$ Longer time periods are already provided for in other federal acts, such as the Federal Act on Radioprotection ${ }^{149}$ or the Product Liability Act, 150 and may also apply where the injury was caused by an act which constitutes a criminal offence. ${ }^{151}$ Claims brought under cantonal public law are subject to the respective Canton's statute of limitations. ${ }^{152}$

\section{Burden of proof}

The burden of proof is allocated by federal law. In general, the person seeking compensation from another must prove that he has suffered damage, that such damage was caused by the alleged tortfeasor, and that such tortfeasor was at fault. ${ }^{153}$ These rules also apply in the area of medical

144 On the consequences of failure to prove informed consent, see infra, nos $89 \mathrm{ff}$.

145 See, eg, Federal Court decision 4C.378/1999 of 23 November 2004, at para 3.1; BGE 123 II 577, 583 (Federal Court decision of 12 September 1997).

146 Art 60 CO (fn 98).

147 See infra, no 83.

148 See the Federal Council's press release of 21 January 2009, available at <http:// www.ejpd.admin.ch/ejpd/de/home/dokumentation/mi/2009/2009-01-21.html> (12.01.11).

149 See Guillod (fn 87) 392, 409 (at para 67).

150 See infra, no 74.

151 Art 60(2) CO (fn 98); see Guillod (fn 87) 392, 409 (at para 66).

152 See infra, no 102.

153 Art 8 of the Swiss Civil Code (CC) (Schweizerisches Zivilgesetzbuch) of 10 December 1907, SR 210. 
malpractice. ${ }^{154}$ Moreover, the damaged party must prove the facts on which he bases his allegation of wrongfulness, eg the doctor's alleged mistake in treatment.

55 In a much-criticised decision, ${ }^{155}$ the Federal Court held that in certain circumstances, the mere fact of a negative outcome may lead to a 'natural presumption' of medical malpractice. ${ }^{156}$ In this case, a patient had received peri- and intraarticular injections of cortisone preparations which ultimately and irreversibly destroyed her humeral head and shoulder socket. According to the Federal Court, 'if a doctor could and should recognise that the proposed medical treatment might have adverse effects, he is required to take all necessary precautions to avoid such effects. If such effects occur, there will be a natural presumption that the doctor failed to take the necessary precautions. ${ }^{157}$ The doctor may rebut this presumption, for example by showing which precautions he took in order to avoid the adverse outcome and that even with the utmost care, a remaining risk could not be avoided. ${ }^{158}$ However, the Federal Court later clarified that not every adverse outcome might establish such a 'natural presumption', and that its decision had been inseparably linked to the particular facts of that case. 159

56 The burden of proof with regard to causation (conditio sine qua non-test) has hitherto not been shifted to the tortfeasor in medical malpractice cases, not even in cases of grave mistake. However, the standard of proof of causation is at least relaxed in medical malpractice cases. ${ }^{160}$ Thus, it is sufficient that the mistake more likely than not caused the damage

154 See, eg, unpublished Federal Court decision 4C.378/1999 of 23 November 2004, at para 3.2; Hausheer (fn 97) paras 15.79 ff; MW Kuhn, Arzt und Haftung aus Kunst- bzw. Behandlungsfehlern, in: Kuhn/Poledna (fn 35) 601, 613; T Sutter-Somm/B Spitz, Beweisfragen im Arzthaftungsprozess, in: Fellmann/Poledna (fn 107) 143, 150 ff; O Guillod, Responsabilité médicale: de la faute objectivée à l'absence de faute, in: C Chappuis/B Winiger, Responsabilités objectives (2003) 155, $159 \mathrm{f}$.

155 See H Hausheer, Country Report: Switzerland, in: M Faure/H Koziol (eds), Cases on Medical Malpractice in a Comparative Perspective (2001) 201, 216 f; idem (fn 97) para 15.83; for further references, see Sutter-Somm/Spitz (fn 154) 143, 152 f.

156 BGE 120 II 248, 250 (Federal Court decision of 29 July 1994).

157 BGE 120 II 248, 250 (Federal Court decision of 29 July 1994).

158 BGE 120 II 248, 250 (Federal Court decision of 29 July 1994).

159 Unpublished Federal Court decision 4C.53/2000 of 13 June 2000, at para 2.b.

160 On the regular standard of proof and its exceptions, see R Brehm, Schadenersatz für Körperschäden in der Schweiz, in: BA Koch/H Koziol (eds), Compensation for Personal Injury in a Comparative Perspective (2003) $325,334 \mathrm{f}$ (at paras 41-48). 
suffered. ${ }^{161}$ Also, where an omission (rather than an act) is at issue, the Federal Court has held that a doctor is required to cooperate in the evidentiary proceedings before the court. ${ }^{162}$ Although the burden of proof is not shifted to the doctor, the court may take a failure to cooperate into account when appreciating the evidence. ${ }^{163}$ The mere possibility of causation is, however, never sufficient. 164

Thus, the patient seeking compensation for medical malpractice faces two hurdles. Firstly, he must prove that a mistake in treatment actually occurred, and secondly, he must prove that such mistake was a conditio sine qua non of the damage suffered. Because of these difficulties of proof, it is generally easier for a patient to allege that he was not properly advised of the risks of an intervention. ${ }^{165}$

In its published case law, the Federal Court has left open the question of whether the burden of proof of causation may exceptionally be shifted to the doctor (or other health care provider) if evidence has been destroyed or concealed, be it intentionally or negligently, or if the clinical records are incomplete. However, in such situations, the court may relax the standard of proof. 166

\section{Uncertain causation}

As pointed out above, ${ }^{167}$ a patient bringing a claim for medical malpractice must at least be able to prove that the treatment more likely than not caused the damage suffered. If this standard of proof is not satisfied, ie if the existence of a causal link between treatment and damage is uncertain, the patient's claim will fail. 168 Thus, if it is unclear whether the patient's situation deteriorated because of the treatment or in the ordinary course of his pre-existing condition, and neither can be said to be the more likely cause of deterioration, liability for medical malpractice will be denied.

161 See, eg, unpublished Federal Court decision 4C.378/1999 of 23 November 2004, at para 3.2; BGE 133 III 462, $470 \mathrm{f}$ (Federal Court decision of 13 June 2007); further references to case law in Jäger/Schweiter (fn 74) $105 \mathrm{ff}$.

162 Unpublished Federal Court decision 4C.53/2000 of 13 June 2000, at para 2.c. See Hausheer (fn 155) 201, 217.

163 Cf BGE 119 II $305 \mathrm{f}$ (Federal Court decision of 17 August 1993).

164 See, eg, Sutter-Somm/Spitz (fn 154) 143, 155. For references to case law, see Jäger/Schweiter (fn 74) $106 \mathrm{ff}$.

165 See supra, no 51 and infra, no 90.

166 See Jäger/Schweiter (fn 74) $108 \mathrm{ff}$.

167 Supra, no 56.

168 On the doctrine of loss of a chance, see infra, no 63. 
60 Under orthodox rules of causation, a person who has suffered damage must also prove the identity of the person who caused such damage. ${ }^{169}$ If a person is unable to prove the identity of the tortfeasor, liability will fail. This also holds true in case of alternative causation, ie where it is established that the damage must have been caused by one of several tortfeasors, but it is impossible to prove which one. ${ }^{170}$ However, if such tortfeasors acted in concert within the meaning of art 50(1) CO, an exception is made and they will be jointly and severally liable. ${ }^{171}$

61 A further exception may apply where the requirements of art 55(1) $\mathrm{CO}^{172}$ are met, although the Federal Court has not yet been called on to decide this issue in a medical context. Thus, if it is established that a member of a certain group of persons must have caused the damage in the course of their work, and all of the group members are subordinated to one and the same 'master', such master should be held liable if he is unable to prove that he took all precautions necessary to prevent the damage. ${ }^{173}$ In this situation, the damaged party should not be required to establish the identity of the person who actually caused the damage. ${ }^{174}$ Rather, liability should turn on the issue of subordination and on the master's (in-)ability to prove that he took all necessary precautions to prevent such harm, in particular with respect to an appropriate organisation. ${ }^{175}$ Nonetheless, the patient will need to prove that his damage was caused by a member of the group (and not by a third person). If the patient alleges that his harm was caused by a mistake in treatment, he will also need to prove such mistake, and that such mistake caused his damage. ${ }^{176}$

62 Accordingly, if it is established that the harm was caused eg by a member of a hospital's staff, without the identity of such staff member being known, the patient may bring a claim against the hospital under art 55(1)

169 See Kuhn (fn 154) 601, $653 \mathrm{f}$.

170 This is probably still the majority opinion in Swiss law (see, eg, Brehm [fn 97] art 41 no $124 \mathrm{ff}$ ), although there is an increasing number of critics (see, eg, Rey [fn 137] paras 623, 624; for further references, see Schnyder [fn 96] art 41 no 25).

171 See Rey (fn 137) paras 625 ff; Brehm (fn 97) art 50 no 6 ff. On joint and several liability, see infra, no 66.

172 See supra, nos $48 \mathrm{ff}$.

173 Cf supra, no 50.

174 Opinion shared by Rey (fn 137) para 898; H Honsell, Schweizerisches Haftpflichtrecht (4th edn 2005) $\mathbb{S} 13$ no 21 . See also Werro, La responsabilité civile (2005) para 456.

175 The only published federal case discussing (and accepting) liability for organisational deficiencies in a medical context is concerned with cantonal public law: see BGE $112 \mathrm{Ib}$ 322 (Federal Court decision of 30 September 1986); see also infra, no 100. However, the Federal Court has applied similar reasoning in product liability cases: see BGE $110 \mathrm{II}$ 456 (Federal Court decision of 9 October 1984).

See supra, nos 54, 56, and 57. 
CO. In such a case, the hospital should be held liable unless it is able to prove that it took all necessary precautions to prevent such harm, in particular with respect to an appropriate organisation. The patient should only be required to prove the identity of the individual who actually caused the harm if he wishes to bring a claim against such individual. ${ }^{177}$

\section{Loss of a chance}

In 2007, the Swiss Federal Court was called upon for the first time to decide whether a cantonal court's refusal to impose liability for loss of a chance was arbitrary. ${ }^{178}$ The scope of the Federal Court's review was limited to the question of arbitrariness as the cantonal court's decision was based on cantonal public law, and not on federal private law, where the scope of review would have been broader. Cantonal public law was at issue as the patient had been treated in a cantonal public hospital. ${ }^{179}$ Although the situation under federal private law has not yet been decided by the Federal Court, the Court did indicate that it considered the loss of chance theory to be problematic. ${ }^{180}$ As such, it is unlikely to recognise this theory under federal private law in the near future. ${ }^{181}$

\section{Multiple persons involved}

Where more than one individual is involved in the provision of medical services to the patient, several different situations must be distinguished with regard to liability in tort:

In the first scenario, all individuals involved in the provision of medical services are employed by one and the same 'master'. As pointed out above,

177 This view was also taken by the Amtsgericht Luzern-Stadt, decision of 26 June 1993 , SG N 895, at para 7.2. Opinion shared by TM Mannsdorfer, Haftung für perinatale Schädigung im medizinischen Bereich, HAVE 2003, 101, 110; J Gross, Haftung für medizinische Behandlung im Privatrecht und im öffentlichen Recht der Schweiz (1987) $251 \mathrm{f}$; cf also Kuhn (fn 154) 601, 654, who is, however, more reserved in his analysis of the situation de lege lata.

178 BGE 133 III 462 (Federal Court decision of 13 June 2007). See C Widmer, A Civil Lawyer's Introduction to Anglo-American Law: Torts (2008) $266 \mathrm{ff}$.

179 See infra, no 96.

180 This sceptical attitude was confirmed in the unpublished Federal Court decision 4A.227/2007 of 26 September 2007.

181 For a discussion of this case, see C Müller, Hat die perte d'une chance in der Schweiz noch eine Chance? - BGE 133 III 462, ZBJV 2007, 862 ff. 
a 'master' may be liable in tort for its 'servants' under art 55(1) CO. ${ }^{182}$ The master-servant relationship turns on the requirement of subordination. ${ }^{183}$ Employees are generally considered to be subordinated to their employers for the purposes of art 55(1) CO. ${ }^{184}$ Thus, a hospital is 'master' in relation to its employees, be they chief physicians, senior physicians, interns, nurses, members of the internal legal department, accountants, or cleaning staff. Although persons lower down in the hospital hierarchy will receive their instructions from, and be supervised by, intermediate staff members, it is always the person at the top of the hierarchy, ie the hospital itself that will qualify as 'master' in relation to lower staff members, not the intermediate staff. 185

66 If something goes wrong in this comparatively straightforward scenario, the hospital will be liable in tort toward the patient under art 55(1) CO, unless it can show that it took all necessary precautions to avoid the damage, in particular with respect to an appropriate organisation. ${ }^{186}$ If the patient is able to identify the individual staff member(s) who actually caused the harm, ${ }^{187}$ he may also choose to sue such individual(s) instead under art 41(1) CO,188 although this will generally be the less attractive route for the patient due to the hospital's 'deeper pockets'. Liability of the hospital and the responsible staff member(s) is joint and several (Solidarität) solidarité/solidarietà), 189 so that the patient may choose whether to bring a claim in an individual action against one of the responsible parties, for all or only part of his damages, or against all liable parties in a joint action. ${ }^{190}$

67 In the second, more complex scenario, one or more affiliated doctors (Belegarzt/médecin agréé) are involved in the provision of medical services to the patient, together with hospital staff members. As before, if the patient is able to identify the individual(s) who actually caused the harm, he may bring a claim against such individual under art 41(1) CO. However, it may be difficult to establish the identity of such individual, or such individual's pockets may not be 'deep' enough. The question then arises whether the

\footnotetext{
182 Supra, nos $48 \mathrm{ff}$.

183 See supra, no 48.

184 But see infra, nos $67 \mathrm{ff}$, on the situation with respect to hospital staff assisting an affiliated doctor.

185 See generally K Oftinger/EW Stark, Schweizerisches Haftpflichtrecht, Band II/1 (4th edn 1987) $\$ 20$ no 73, 79; Rey (fn 137) para 905; Werro (fn 174) para 450.

186 See supra, nos 50 and $61 \mathrm{f}$.

187 On this condition, see supra, nos $60 \mathrm{ff}$.

188 On the requirements under art 41(1) CO, see supra, no 47.

189 Art 51 CO (fn 98).

190 Art 144(1) CO (fn 98). See also Mannsdorfer, HAVE 2003, 101, 117.
} 
individuals involved in the provision of medical services to the patient are subordinated to a 'master' for the purposes of art 55(1) CO, and if so, who that 'master' is.

First of all, the affiliated physician himself is not subordinated to the hospital, and accordingly, the hospital cannot be held liable for any of the affiliated doctor's mistakes. ${ }^{191}$ However, the situation is less clear if a mistake is made by a member of the hospital staff. Although staff members are employed by the hospital, there are situations where the affiliated doctor, and not the hospital, will be classified as 'master' under art 55(1) CO. Thus, the affiliated doctor will qualify as 'master' if the mistake occurred in a phase where the responsible staff member was subject to the affiliated doctor's supervision and authority to issue directives, for example whilst assisting during an operation under the affiliated doctor's guidance. In contrast, the hospital will qualify as 'master' if a mistake is made by a staff member in an area where such member is subject to the hospital's supervision and authority to issue directives, for example whilst taking care of the patient prior to the affiliated doctor's arrival. ${ }^{192}$

Once the 'master' is identified in this second scenario, he will be liable toward the patient under art 55(1) CO unless he can show that he took all necessary precautions to avoid the damage. ${ }^{193}$ If the patient is able to identify the individual(s) who actually caused the harm, he may also choose to sue such individual(s) under art 41(1) CO. Liability of the master and the responsible individual(s) is joint and several.194

Where several specialist doctors are on an operating team together, they $\mathbf{7 0}$ will generally not be subordinated to one another for the purposes of art 55(1) CO. However, this will depend on the structure and organisation of the specific team. ${ }^{195}$ If all of the specialists are employed by one and the same hospital, such hospital will qualify as the 'master' under art 55(1) CO. 196

191 Mannsdorfer, HAVE 2003, 101, 117.

192 See ibid, 101, 117; cf also C Götz Staehelin, Teamarbeit und geteilte Verantwortung in Spital, Arztpraxis und Belegarztverhältnis, HAVE 2007, 226, 233.

193 See supra, no 50.

194 Cf already supra, no 66.

195 See Götz Staehelin, HAVE 2007, 226, 233.

196 On this straightforward scenario, see supra, no 65. 


\section{Strict liability}

71 Under federal private law, strict liability of private hospitals, private practitioners or other health care providers is available only in very restricted situations. Strict liability under cantonal public law will be dealt with separately. 197

72 If a patient is harmed by a defective product, such as a drug, medical device or technical equipment, 198 the producer of such product may become liable toward the patient under the federal Product Liability Act. ${ }^{199}$ A health care provider may qualify as a 'producer' in case of activities such as the preparation of medical products (eg sterilisation of unsterile medical products). ${ }^{200}$ Moreover, any health care provider who imports a product for commercial distribution in Switzerland is considered a 'producer' under the Act. ${ }^{201}$ The Act is based on the EC directive of 5 July 1985. Liability under the Act is strict. Accordingly, the producer may be held liable regardless of fault. ${ }^{202}$

73 Any moveable thing, including those things which form a component part of another moveable thing or of an immoveable thing, constitutes a 'product' under the Act. ${ }^{203}$ Other than drugs, medical devices and technical equipment, blood and human organs also constitute products once they have been separated from the body and prepared. ${ }^{204}$

74 Other than the fact that liability under the Act is strict, product liability law also deviates from general tort rules with regard to the statute of limitations. Thus, claims brought under the Act are time-barred three years from the day the harmed person acquired - or should have acquired - knowledge of the damage, the defect and the producer's identity. ${ }^{205}$ Moreover, liability under the Act cannot be limited or excluded.206

197 See infra, nos $95 \mathrm{ff}$.

198 On the meaning of 'defective' in the medical context, see M Gattiker, Arzt und Medizinprodukt, in: Fellmann/Poledna (fn 107) 495, 526 ff.

199 See art 2 of the Federal Product Liability Act (PLA) (Bundesgesetz über die Produktehaftpflicht [Produktehaftpflichtgesetz, PrHG]) of 18 June 1993, SR 221.112.944.

200 See Gattiker (fn 198) 495, 525 ff.

201 Cf art 2(1)(c) PLA (fn 199); see Gattiker (fn 198) 495, 526.

202 See, eg, Rey (fn 137) paras $1167 \mathrm{ff}$.

203 Art 3 PLA (fn 199).

204 W Fellmann in: Honsell et al (fn 96) art 3 PrHG no 4; Honsell (fn 174) $\$ 21$ no 29. Special rules apply to liability for harm caused by xenotransplants; see arts $3(2)(\mathrm{b})$ and $5\left(1^{\text {bis }}\right)$ PLA (fn 199).

205 Art 9 PLA (fn 199). On the one-year period under the general statute of limitations (art 60 CO), which only starts to run in case of actual knowledge, see supra, no 53.

206 Art 8 PLA (fn 199). 
Strict liability may also be available in the case of clinical drug trials. 75 Under federal law, clinical drug trials may only be conducted if it is ensured that test persons will be fully compensated for any damage suffered in the course of the trial. ${ }^{207}$ Although the wording of federal law is not unequivocal and its meaning has not yet been clarified by the Federal Court, such liability is generally considered to be strict. 208 It has also been suggested that the standard of proof with regard to causation is relaxed as the test person is only required to show that harm was suffered 'in the course of the clinical trial'. ${ }^{209}$ As under the Product Liability Act, it is argued that liability in case of clinical drug trials cannot be limited or excluded. ${ }^{210}$ However, many questions remain open. ${ }^{211}$

In a certain sense, liability for failure to obtain informed consent as devel- $\mathbf{7 6}$ oped by the Federal Court can also be considered strict, 212 as the doctor who proceeds without such consent will become liable for all damage suffered in consequence of the medical intervention, including damage which was caused simply by chance, as long as such damage is not too remote. ${ }^{213}$

\section{Contractual Liability}

\section{Basics of contracts in the health care sector}

If a patient with the capacity to act seeks medical advice or treatment from $\mathbf{7 7}$ a private practitioner, a private hospital or other private health care provider, such patient will, as a rule, ${ }^{214}$ enter into a private law contract with such provider. Private law contracts for provision of medical services are traditionally classified as a mandate (Auftrag/mandat/mandato). ${ }^{215}$ This

207 Art 54(1)(a)(5) and (1)(b) DMPA (fn 104) in conjunction with art 7(2) CTR (fn 104).

208 See D Sprumont/M-L Béguin, La nouvelle réglementation des essais cliniques de médicaments, SÄZ No 18/2002, 894, 900; O Guillod/P Schweizer, Expérimentation de nouveaux médicaments et responsabilité civile, in: P Tercier (ed), Aspects de droit médical (1987) 93; J Gross, Staatshaftung und Heilmittelrecht, leges 1/2003, 137, 138; D Sprumont/ $S$ Boillat/H Amstad, Essais cliniques, responsabilité civile et contrats d'assurance, SÄZ No. 40/2002, 2092, 2093; Gattiker (fn 198) 495, 519.

209 Sprumont/Béguin, SÄZ No 18/2002, 894, 900.

210 Ibid, 894, 899, 900.

211 See Gattiker (fn 198) 495, 519 f, with further references.

212 See Guillod (fn 87) 392, 399 (at para 26).

213 See infra, no 90.

214 For the exceptions to this rule, see supra, no 45.

215 Arts $394 \mathrm{ff}$ CO (fn 98). See, eg, BGE $132 \mathrm{III}$ 359, $362 \mathrm{f}$ (Federal Court decision of 20 December 2005); W Fellmann, Die Haftung des Privatarztes und des Privatspitals, in: Fellmann/Poledna (fn 107) 47, 49 ff; id (fn 111) 103, 106; Guillod (fn 87) 392, 393 (at para 3). 
also applies to contracts between patients and private hospitals, at least insofar as the provision of care and medical services (and not, eg, catering) is concerned. ${ }^{216}$

78 In the case of stationary medical care in a private hospital, two different scenarios must be distinguished. ${ }^{217}$ In the first, the patient enters into only one contract, namely with the hospital. Under this so-called 'comprehensive hospital contract' (totaler Spitalaufnahmevertrag/contrat global d'hospitalisation), the hospital is contractually bound to provide the patient with accommodation, catering, care and medical treatment, and the patient is contractually bound to remunerate such services. Accordingly, if something goes wrong in the course of medical treatment, a contractual claim for medical malpractice can only be brought directly against the hospital. The responsible doctor will be considered an auxiliary of the hospital under art 101(1) CO, so that his acts or omissions will be imputed to the hospital for the purposes of liability. ${ }^{218}$ If the patient wishes to sue the responsible doctor, he may do so; in this case, hospital and doctor will be jointly and severally liable. ${ }^{219}$ However, as the patient only has a contract with the hospital and not with the doctor, any claim against the doctor will of necessity be a tort claim.220

79 In the second scenario, the patient also enters into a contract with the hospital. However, the hospital is only contractually bound to provide the patient with accommodation, catering, and care (so-called 'fractioned hospital contract'; gespaltener Spitalaufnahmevertrag/contrat partiel d'hospitalisation). In contrast, medical treatment is provided on the basis of a separate contract between the patient and the doctor who is treating the patient in the hospital. ${ }^{221}$ Accordingly, if something goes wrong in the course of treatment, the question will arise whether the measure which caused the harm was within the remit of the hospital or the doctor. Whether or not a contractual claim can be brought against the hospital or the doctor in this second scenario will depend on the outcome of this assessment.222 The doctor's acts and

216 Fellmann (fn 111) 103, 106, 107.

217 See Guillod (fn 87) 392, 393 (at para 5); Fellmann (fn 111) 103, 106 f; M Amstutz/W Schluep in: Honsell et al (fn 96) Einl vor art $184 \mathrm{ff}$ no $343 \mathrm{ff}$.

218 See infra, no 85.

219 Art $51 \mathrm{CO}$ (fn 98). On the consequences of joint and several liability, see supra, no 66.

220 Fellmann (fn 215) 47, 51; Amstutz/Schluep (fn 217) Einleitung vor art 184 ff no 355.

221 Fellmann (fn 215) 47, 51.

222 See Amtsgericht Luzern-Stadt, decision of 26 June 1993, SG N 895, at para 7.2; Gross (fn 177) 249 f, 254 ff; see also Amstutz/Schluep (fn 217) Einl vor art 184 ff no 356; Fellmann (fn 111) 103, 107. 
omissions cannot be imputed to the hospital under art 101(1) $C O, 223$ as the hospital is not contractually bound to provide medical treatment.

If a patient is treated in a public hospital, the relationship between hospital and patient will be subject to public law. ${ }^{224}$ If the patient is a private patient of one of the hospital's doctors, such patient will also enter into a private law contract with such doctor. 225 Nonetheless, it does not necessarily follow that hospital doctors will become personally liable toward their private patients if something goes wrong during treatment, as the Cantons have the power to preempt federal private law with regard to the liability of their employees. 226

In general, the social health system has no impact on the relationship between patients and health care providers.227 However, an exception applies with regard to the question of who is bound to pay the health care provider's fees. In the case of social health insurance coverage, the rule is that the patient will pay the health care provider's fees directly. The patient will then be entitled to reimbursement from the insurer (so-called tiers garant-system). Nonetheless, insurers and health care providers may deviate from this rule by agreeing that the insurer, and not the patient, will be the health care provider's debtor (so-called tiers payant-system).228 Also, where a patient requires stationary care, the rule is reversed under federal law, so that the health care insurer will always be the health care provider's debtor. ${ }^{229}$ In the case of social accident insurance coverage, the health care provider's debtor is generally the insurer, and not the patient. ${ }^{230}$

\section{Differences to tort law}

Under art 97(1) of the Code of Obligations (CO),231 four requirements must be met for liability in contract. Firstly, a person must have suffered damage, ie a pecuniary loss. Secondly, there must be a breach of contract. Thirdly, there must be a causal link between the breach and the damage

223 Cf infra, no 85.

224 See infra, no 96.

225 The same apples if the public hospital allows for medical treatment by affiliated doctors; see Fellmann (fn 111) 103, $110 \mathrm{ff}$.

226 See infra, no 97 and the references in fn 280.

227 See supra, no 24.

228 See art 42 HIA (fn 6).

229 Art 42(2) HIA (fn 6).

230 Gächter/Vollenweider (fn 5) para 732.

231 See supra, fn 98. 
suffered, ie the breach must be a conditio sine qua non of the damage, and such damage must not be too remote. ${ }^{232}$ Finally, the potentially liable party must be at fault, ie he must be of sufficient mental capacity and must have acted either intentionally or negligently. These requirements also apply to contracts for the provision of medical treatment. ${ }^{233}$

83 If the requirements for both contractual and tort liability are met, patients who are harmed in the course of medical treatment are free to choose whether to bring their claim in contract or in tort. ${ }^{234}$ However, contractual claims are generally more advantageous. ${ }^{235}$ Thus, the statute of limitations for contractual claims is ten years from the date on which the claim was due, ${ }^{236}$ whereas in tort, the regular limitation period is one year from the day the harmed person acquired knowledge of the damage and the tortfeasor's identity. 237

84 A further distinction between claims in contract and tort relates to the burden of proof with regard to fault. In tort claims, it is the harmed party who must prove that the alleged tortfeasor acted intentionally or negligently, whereas in contract claims, the burden of proof is shifted to the party in breach under art 97(1) CO. Unless such party succeeds in showing that he bears no fault, such fault will be presumed for the purposes of liability. However, where medical malpractice is concerned, this advantage has little practical impact.238 In a contractual claim for medical malpractice, the patient must prove that the health care provider breached the contract by violating professional standards, ie by not acting lege artis. ${ }^{239}$ If the patient succeeds in proving such breach, it will be practically impossible for the health care provider to free himself from liability by showing that he was not at fault. Accordingly, the central question is whether the health care provider breached the contract, and that is for the patient to prove. ${ }^{240}$ In tort claims, an alleged violation of professional standards must also be proved by the patient, namely in the context of wrongfulness. ${ }^{241}$ Both in tort and in contract claims, the requisite stand-

\footnotetext{
232 For the corresponding requirements in tort law, see supra, no 47.

233 See, eg, BGE 133 III 121, $123 \mathrm{ff}$ (Federal Court decision of 9 February 2007).

234 See, eg, I Schwenzer, Schweizerisches Obligationenrecht Allgemeiner Teil (5th edn 2009) para 5.03.

235 See, eg, Schwenzer (fn 234) para 5.04.

236 Art 127 in conjunction with art 130(1) CO (fn 98).

237 See supra, no 53.

238 See generally Werro (fn 174) para 1481.

239 See, eg, BGE 133 III 121, 124 (Federal Court decision of 9 February 2007).

240 See, eg, BGE 133 III 121, 126-127 (Federal Court decision of 9 February 2007).

241 See supra, no 54.
} 
ard of care is the same. ${ }^{242}$ As in tort, a doctor is also liable in contract for any fault, regardless of the degree. ${ }^{243}$

Another difference between contractual and tort liability is that a debtor's contractual responsibility for auxiliaries is more far-reaching than in tort law, and thus more advantageous to the claimant. Unlike in tort, where a relationship of 'subordination' is required,244 acts and omissions of an auxiliary are generally imputed to the debtor under art 101(1) CO, as long as the auxiliary's conduct can be classified as a breach of contract. ${ }^{245}$ Any person acting with a view to executing the debtor's contractual obligations with the debtor's consent and knowledge qualifies as an auxiliary for the purposes of liability, including independent third parties. ${ }^{246}$ Moreover, the debtor cannot escape liability by showing that he exercised all due diligence. ${ }^{247}$ Neither the debtor's nor the auxiliary's fault is required for liability; rather, it is sufficient that the debtor would have been at fault had he acted in the same way as the auxiliary (so-called 'hypothetical fault'). ${ }^{248}$ It is for the debtor to prove that the auxiliary complied with the standard of care owed by the debtor. ${ }^{249}$

Insofar as the patient's claims are concerned, the same types of damages are compensable both in tort and in contract. Claims for non-pecuniary loss are also available both in tort and in contract. ${ }^{250}$ However, damages claims by the victim's relatives for wrongful death can only be based in tort, not in contract. ${ }^{251}$ In principle, ${ }^{252}$ this also applies to claims for non-pecuniary loss brought by a disabled victim's relatives, as well as to independent claims for non-pecuniary loss brought by a deceased victim's relatives. ${ }^{253}$

242 BGE 115 Ib 175, 810 (Federal Court decision of 17 May 1989).

243 See BGE 133 III 121, 124 (Federal Court decision of 9 February 2007); cf also supra, no 47 in fine.

244 Art 55(1) CO; see supra, no 48.

245 See Schwenzer (fn 234) paras $23.07 \mathrm{ff}$.

246 See, eg, ibid, para 23.04.

247 Contrast art 55(1) CO; see supra no 50.

248 See, eg, Schwenzer (fn 234) para 23.10; for an example from case law, see Amtsgericht Luzern-Stadt, decision of 26 June 1993, SG N 895, at paras $6.2 \mathrm{ff}$ (liability of a hospital for acts of its auxiliaries).

249 See P Gauch/W Schluep/S Emmenegger, Schweizerisches Obligationenrecht vol 2 (9th edn 2008) para 3049; unpublished Federal Court decision 4C.307/2003 of 19 February 2004, at para 5.2; BGE 119 II 337, 338 (Federal Court decision of 22 June 1993). Cf BGE 123 III 204, 206-207 (Federal Court decision of 9 June 1997).

251 BGE 123 III 204, 207 (Federal Court decision of 9 June 1997).

252 See infra, no 137.

253 BGE 123 III 204, 213 (Federal Court decision of 9 June 1997). On the practical consequences, see infra, no 137. 


\section{Contractual claims in the absence of direct contracts?}

87 In certain limited circumstances, a patient who has not entered into a contract with a health care provider may nonetheless be able to base a claim on the violation of contractual duties. If, for example, a patient lacks the capacity to act, he cannot conclude a contract for the provision of medical services on his own behalf. Rather, his legal guardian must act for him. Depending on the circumstances of the case,254 the legal guardian will either act as the patient's agent, so that the contract will be concluded directly between the health care provider and the patient, or the contract will be concluded between the health care provider and the legal guardian. In the latter case, the patient is not a party to the contract. Nonetheless, if something goes wrong in the course of medical treatment, the patient will have a contractual claim against the health care provider, as the contract was entered into for the patient's benefit. 255

88 In contrast, the concept of contracts with protective effect for third parties (Vertrag mit Schutzwirkung zugunsten Dritter/contrat avec effet protecteur envers des tiers/contratto con effetto di protezione a favore di terzi) has not hitherto been adopted by the Federal Court ${ }^{256}$ and remains controversial in Swiss law.257 Accordingly, it is doubtful whether a patient basing his claim on a violation of the contract between (eg) the hospital and the doctor would be successful.

\section{Informed consent}

89 The doctrine of informed consent can become relevant both in tort and in contract claims for medical malpractice. As pointed out above,258 a patient alleging medical malpractice must prove that the medical treatment was not lege artis, which can be difficult. Both in contract and in tort, however, it is the doctor (or, if the hospital's liability is at issue, the hospital) who must prove that the patient gave informed consent. ${ }^{259}$

\footnotetext{
254 See Schwenzer (fn 234) paras $86.11 \mathrm{f}$.

255 See art 112(2) CO (fn 98). Cf BGE 116 II 519, 520 (Federal Court decision of 23 October 1990); Schwenzer (fn 234) para 86.11.

256 Question left open in BGE 130 III 345, 347-348 (Federal Court decision of 23 December 2003).

257 See Schwenzer (fn 234) paras $87.01 \mathrm{ff}$.

258 Supra, nos 51 (for tort claims) and 84 (for contract claims).

259 For tort claims, see supra, para 51; for contract claims, see BGE 133 III 121, 129 (Federal Court decision of 9 February 2007).
} 
Swiss law not only recognises medical malpractice in its narrower sense, but also a distinct cause of action for failure to obtain informed consent. 260 If something goes wrong during a medical intervention and it cannot be shown that the patient gave his informed consent, the consequences are drastic. The doctor will be held liable for all damage suffered in consequence of the intervention, regardless of whether such damage was caused by a mistake in treatment or simply by chance, as long as such damage is not too remote. ${ }^{261} \mathrm{He}$ may only avoid liability if he can show that the individual patient would have consented to the intervention even if he had been properly informed (so-called 'hypothetical consent'). ${ }^{262}$ If he fails, the patient will only be required to show that he suffered damage as a consequence of the intervention (eg surgery) as such. ${ }^{263}$ This will generally be an easy task. Accordingly, questions surrounding informed consent are of great practical importance, and it is the rule, rather than the exception, that a patient will allege lack of informed consent in medical malpractice cases. ${ }^{264}$

The legal requirements of informed consent have been developed in case law, although there are statutory rules in particularly sensitive areas, such as reproductive medicine, organ transplantation or genetic testing. ${ }^{265}$ Informed consent also forms one of the cornerstones of the Oviedo Convention on Human Rights and Biomedicine. ${ }^{266}$ Cantonal law may provide additional statutory rules on the scope of the duty to inform. ${ }^{267}$ The Swiss Medical Association's rules of professional conduct ${ }^{268}$ also provide that doctors must inform their patients, ${ }^{269}$ as do various guidelines of the Swiss Academy of Medical Sciences (SAMW). ${ }^{270}$

260 See, eg, Hausheer (fn 155) 201, 212.

261 See, eg, BGE 108 II 59, 62 (Federal Court decision of 12 January 1982); BGE 133 III 121, 128 (Federal Court decision of 9 February 2007). See also Guillod (fn 87) 392, 398 (at para 23). On the test of remoteness in contract and tort claims, see supra, nos 47 and 82.

262 See, eg, BGE 133 III 121, 130 (Federal Court decision of 9 February 2007); unpublished Federal Court decision 4.C.66/2007 of 9 January 2008, at para 5; Hausheer (fn 155) 201, 209 f; Fellmann (fn 111) 103, 227 ff. For further references to case law, see Jäger/Schweiter (fn 74) 86 ff.

263 See, eg, BGE 108 II 59, 62-63 (Federal Court decision of 12 January 1982).

264 See, eg, Guillod (fn 87) 392, 399 (at para 26). For a critique of this development, see Roberto (fn 143) paras 93 ff; Honsell (fn 174) $\mathbb{S} 5$ no 22.

265 See Guillod (fn 87) 392, 398 (at para 24); Fellmann (fn 111) 103, 182 ff.

266 See arts 5-9 of the Oviedo Convention (Übereinkommen zum Schutz der Menschenrechte und der Menschenwürde im Hinblick auf die Anwendung von Biologie und Medizin [Übereinkommen über Menschenrechte und Biomedizin]) of 4 April 1997, SR 0.810.2.

See Jäger/Schweiter (fn 74) 68, 69.

268 See supra, no 38.

269 See art 10 (fn 114).

270 On the guidelines of the SAMW, see supra, no 39. 
92 The purpose of informed consent is to provide adequate information to the patient so that he can make an intelligent decision about a given diagnostic or therapeutic procedure. The scope of the duty to inform patients depends on the nature and the possible consequences of the medical treatment involved. ${ }^{271}$ In broad terms, the patient should receive all the information necessary for him to be able to decide whether or not to agree to the proposed intervention. The individual patient's information needs are decisive, not those of a 'reasonable' patient. ${ }^{272}$ Information must be given early enough for the patient to be able to reach a decision without pressure. In the case of heavy surgery or if grave risks are involved, a patient must be informed at least three days beforehand, unless there is an emergency. Otherwise, one day beforehand is sufficient. ${ }^{273}$

93 In particular, 274 doctors are under a duty to inform their patients of the nature of the proposed treatment and the risks involved, except in case of commonplace measures which neither pose a serious threat to the patient's health nor may lead to irrevocable harm or long-term impairment. There is no duty to inform of risks which are generally involved with all larger interventions, such as bleeding, infections, thrombosis or embolisms. In contrast, the patient must be informed of specific risks of the proposed intervention, as well as of rare risks with serious consequences. In general, statistical risk percentages are not used for determining the scope of the duty to inform. ${ }^{275}$

94 The doctrine of informed consent is limited by the so-called 'therapeutic privilege', meaning that a doctor need not (and indeed must not) give information which might induce a state of anxiety in the patient such as to injure the patient's health. 276

271 See Fellmann (fn 111) 103, 167 ff; Hausheer (fn 155) 201, 203 ff.

272 See W Wiegand, Die Aufklärungspflicht und die Folgen ihrer Verletzung, in: H Honsell (ed), Handbuch des Arztrechts (1994) 119, 136 ff; Fellmann (fn 111) 103, 179.

273 See unpublished Federal Court decision 4P.265/2002 of 28 April 2003, at para 5.2; Guillod (fn 87) 392, 399 (at para 25).

274 For references to pertinent case law, see Jäger/Schweiter (fn 74) 76 ff; see also Fellmann (fn 111) 103, 173 ff, 178 ff; Wiegand (fn 272) 119, 127 ff, 134 ff; Hausheer (fn 155) 201, 205 ff; Guillod (fn 87) 392, 397 (at paras 19 ff).

275 On this latter issue, see Wiegand (fn 272) 119, 134 f; Fellmann (fn 111) 103, 180, 181.

276 For references to case law, see Jäger/Schweiter (fn 74) 76. 


\section{Public Liability}

\section{Key differences from cases involving private hospitals or doctors}

Where a patient is injured in a public hospital, the first question which arises relates to the law governing (1) the relationship between the patient and the hospital (or, where the hospital does not have an independent legal personality, with the hospital proprietor), and (2) the relationship between the patient and the hospital's employees, in particular its doctors.

The liability of public legal entities in Switzerland is not governed by $\mathbf{9 6}$ federal private law, but by federal public law (in the case of federal entities) or cantonal public law (in the case of cantonal entities). 277 With a very few exceptions, ${ }^{278}$ public hospitals in Switzerland are either cantonal or municipal. Accordingly, the liability of such hospitals (or, where applicable, the hospital proprietor) is governed by the respective Canton's public law. According to the majority opinion, this also applies in cases of privatisation. ${ }^{279}$

As far as the relationship between a patient and the public hospital's employees, including hospital doctors, is concerned, the Cantons are free to deviate from the liability regime under federal private law by subjecting such persons' liability to cantonal public law. This power to preempt federal private law also extends to a doctor's relationship with his private patients. 280

If the Cantons do not make use of this power, the provisions of federal

private law will apply by default, so that a hospital doctor may become liable toward a patient under the provisions of the Swiss Code of Obligations. ${ }^{281}$ Accordingly, the liability of doctors employed by a public hospital may be governed by federal private law or by cantonal public law, depending on the legislation of the Canton where the hospital is located. ${ }^{282}$ To date,

277 Art 59 CC (fn 153).

278 See Guillod (fn 87) 392, 402 (at para 38).

279 On this and on other instances where cantonal public law might apply, see supra, no 45.

280 See, eg, BGE 122 III 101, 104-105 (Federal Court decision of 11 March 1996); Guillod (fn 87) 392, 408 (at paras 62 ff); Gross (fn 131) 35, 36 f; Fellmann (fn 111) 103, 111. For further references to case law, see Jäger/Schweiter (fn 74) $12 \mathrm{ff}$.

281 See fn 98.

282 See, eg, Fellmann (fn 111) 103, 112 ff; Eichenberger (fn 74) 351, 359. For an overview of the pertinent decisions of the Swiss Federal Court, see Jäger/Schweiter (fn 74) $4 \mathrm{ff}$. On liability under federal private law, see supra, nos $45 \mathrm{ff}$ and nos $77 \mathrm{ff}$. 
all Cantons have made use of their power to legislate in this area..283 Although each of the 26 Swiss Cantons has its own distinct public law, most cantonal liability regimes are similar.

99 Liability under cantonal public law may differ in several ways from the liability regime under federal private law. The majority of Cantons provide for the exclusive liability of the State, meaning that any claims for pecuniary or non-pecuniary loss may only be brought against the State, and not against the responsible State employee. The Canton may have a right of recourse against the responsible employee, but this is generally restricted to cases where such employee caused the damage intentionally or through gross negligence. ${ }^{284}$

100 In most Swiss cantons, fault is not a requirement for State liability. ${ }^{285}$ In particular, this means that the Canton cannot avoid liability by showing that it exercised all due diligence in selecting, instructing and overseeing its employees and that all work processes were organised diligently. ${ }^{286}$ Accordingly, a patient will not have to identify the actual tortfeasor in claims against the Canton. ${ }^{287}$ The Federal Court has also accepted liability for organisational deficiencies under cantonal public law. ${ }^{288}$

101 However, the Canton will only be liable for acts which are wrongful (widerrechtlich/illicite/illecito). The notion of 'wrongfulness' corresponds to that which is used in federal private law. Accordingly, any interference with a patient's physical integrity constitutes wrongfulness, so that the Canton will have to prove that the patient gave his informed consent. ${ }^{289}$ If this can be proved, the intervention will only be considered wrongful if the patient can show that the intervention was not lege artis. ${ }^{290}$ As far as the

283 Gross (fn 131) $35 \mathrm{f}$.

284 See, eg, $\int \mathbb{S} 6(1), 6(4)$ and 15(1) of the Public Liability Act of the Canton of Zurich (Haftungsgesetz) of 14 September 1969, accessible at <http://www.zhlex.zh.ch> (12.01.11); $\mathbb{S S} 3(1), 3(2)$ and 9 of the Public Liability Act of the Canton of Basel-Stadt (Gesetz über die Haftung des Staates und seines Personals [Haftungsgesetz, HG]) of 17 November 1999, accessible at <http://www.gesetzessammlung.bs.ch> (12.01.11); see also Gross (fn 131) 35, 37; Guillod (fn 87) 392, 404 (at para 44).

285 See Guillod (fn 87) 392, 404 (at paras 47 ff) for references to cantonal law.

286 Contrast art 55(1) CO (see supra, no 50).

287 Cf Gross (fn 131) 35, 39 ff; Kuhn (fn 154) 601, 654; see also the references in fn 177, supra.

288 BGE 112 Ib 322 (Federal Court decision of 30 September 1986). On the unclear situation in federal tort law, see supra, nos $61 \mathrm{f}$.

289 See supra, no 51.

290 See, eg, BGE 123 II 577, 583 (Federal Court decision of 12 September 1997) with further references. 
burden of proof is concerned, the situation of the patient is no different from that under (federal) tort and contract law.

Claims brought under cantonal public law are subject to the respective 102 Canton's statute of limitations, which may differ from the limitation periods provided under federal private law. 291

Finally, the nature of the law governing liability (ie federal private law or cantonal public law) can also have an impact on jurisdiction and procedural rules. Cantonal courts with jurisdiction to hear civil cases do not necessarily have jurisdiction over cases governed by public law, and different procedural rules apply to civil law and public law cases. However, most cantonal laws provide that public liability claims fall within the jurisdiction of civil law courts, and accordingly, the laws on civil procedure will apply. ${ }^{292}$ Until recently, each Canton had its own distinct laws on civil procedure. However, on 1 January 2011, the different cantonal laws were replaced by the new Federal Act on Civil Procedure. ${ }^{293}$

\section{E. Alternative compensation regimes}

\section{Funds and/or other alternative compensation regimes}

There are currently no funds or alternative compensation regimes offering compensation (in whole or in part) to victims of medical malpractice. A proposal to introduce a private compensation fund was made in $2002^{294}$ but has not been implemented to date.

291 See Guillod (fn 87) 392, 409 (at para 68). On the general limitation period in federal tort law, see supra, no 53 .

292 See, eg, $\mathbb{S} 19$ of the Public Liability Act of the Canton of Zurich (fn 284); $\mathbb{S} 6(1)$ of the Public Liability Act of the Canton of Basel-Stadt (fn 284); see also J Gross, Schweizerisches Staatshaftungsrecht (2nd edn 2001) 143, 361; Guillod (fn 87) 392, 413 (at para 84); T Jaag, Öffentliches Entschädigungsrecht: Gemeinsamkeiten und Unterschiede zwischen verschiedenen Formen öffentlichrechtlicher Entschädigungen, Schweizerisches Zentralblatt für Staats- und Verwaltungsrecht (ZBL) 1997, 145, $166 \mathrm{f}$.

293 See supra, no 8.

294 Joint proposal by the Swiss Society for Health Care Policy (SGGP/SSPS), the Swiss Medical Association (FMH), the Red Cross and the journal 'Beobachter'; see Guillod (fn 154) $155,169$. 


\section{F. Extent of Liability/Remedies}

\section{Pecuniary loss}

\section{Introduction to indemnifying pecuniary loss}

105 The general principle in Swiss law is that the tortfeasor is liable for all pecuniary loss caused by the tortious act, as long as such damage is not too remote. ${ }^{295}$ The aim of compensation for pecuniary loss is to place the injured person in the position in which he would have been had the tortious event not occurred. ${ }^{296}$ Punitive damages are not available. ${ }^{297}$

106 The person claiming compensation must prove that he has suffered pecuniary loss, and quantify such loss. 298 If it is impossible to prove or quantify the loss, the court may use its discretion to determine the loss, giving due consideration to the 'ordinary course of things' (gewöhnlicher Lauf der Dinge/cours ordinaire des choses/ordinario andamento delle cose) and the measures taken by the injured person. ${ }^{299}$ Such difficulties of proof are typical of claims for future pecuniary loss.

107 It is in the court's discretion to decide whether the pecuniary loss suffered by a claimant shall be compensated in kind (Naturalrestitution/réparation en nature/risarcimento in natura) or through a monetary award (art $43 \mathrm{CO}$ ). The Code of Obligations ${ }^{300}$ does not give preference to one or the other type of compensation. In practice, however, monetary relief is the rule.

108 Compensation is calculated on the basis of the loss actually suffered by the individual claimant ('subjective-concrete' method, as opposed to the 'objective-abstract' method), 301 although certain exceptions have been recognised by the Federal Court. Thus, no actual loss is required in case of socalled 'household damage' 302 or where an injured person is taken care of at home by friends or relatives. 303

295 See, eg, Schwenzer (fn 234) para 15.07. On the test of remoteness in tort claims, see supra, no 47.

296 See, eg, Brehm (fn 97) art 41 no 70.

297 See Widmer (fn 178) 300.

298 Art 41(1) CO (fn 98).

299 Art 42(2) CO (fn 98). For details, see Brehm (fn 97) art 42 no 1 ff.

300 Supra fn 98.

301 See, eg, BGE 129 III 135, 141 (Federal Court decision of 19 December 2002); Schnyder (fn 96) art 42 no 2-3; Werro (fn 174) paras $928 \mathrm{ff}$.

302 See infra, no 117.

303 See infra, no 111. 
Compensation should not lead to an enrichment of the injured person. ${ }^{304}$ Accordingly, if the injured person receives any monetary benefits owing to the tortious conduct, such benefits will be taken into account when determining the loss (Vorteilsanrechnung/imputation des avantages/imputazione dei vantaggi). This also applies if a third party is statutorily or contractually obligated to make a contribution because of the injury (eg statutory sick pay by the injured person's employer), although such party may be entitled to take recourse against the tortfeasor. ${ }^{305}$ Benefits are not deducted if such deduction is excluded by statutory provisions (eg in the case of fixed-benefit insurance) ${ }^{306}$ or by the intention of the parties (eg in the case of voluntary contributions by the injured person's employer). ${ }^{307}$

If tortious conduct leads to bodily injury, the injured party is entitled to compensation for all costs incurred as a result of the injury (damnum emergens), eg first aid costs, transportation costs, hospital fees, expenditure for medical drugs and devices, as well as to compensation for loss of earnings (lucrum cessans) (art $46 \mathrm{CO}$ ). ${ }^{308}$ If the injured person will receive less social retirement benefits as a result of his reduced income, the tortfeasor will also be liable for such 'retirement damage' (Rentenschaden/ dommage de rente/danno di rendita). 309

Compensation is also owed for costs and losses suffered by relatives when visiting the injured person in hospital (ie costs of the trip and loss of earnings). If the injured person is cared for at home by friends or relatives at no charge, compensation is available on the basis of the average cost of home care, even if no actual loss has been suffered. ${ }^{310}$ In such cases, compensation is due to the injured party himself. The (rather far-fetched) dogmatic construction is that such relatives would be entitled to claim remuneration from the injured party for their visiting costs or the provision of care, so that their claims against the injured party (even if they never actually arise) constitute additional items of damage. ${ }^{311}$

304 See, eg, Werro (fn 174) paras 942 ff; Brehm (fn 97) art 42 no 27 ff; Schnyder (fn 96) art 42 no 7.

305 On the right of recourse of social insurers, see supra, nos $27 \mathrm{ff}$.

306 See art 96 AIC (fn 92).

307 See, eg, Brehm (fn 97) art 46 no 38 f; Rey (fn 137) para 215.

308 For details, see Brehm (fn 97) art 46 no 7 ff.

309 See, in particular, BGE 129 III 135, 141 (Federal Court decision of 19 December 2002).

310 See unpublished Federal Court decision 4C.276/2001 of 26 March 2002, at paras 6.b.aa and 6.b.bb; BGE 97 II 259, 266 (Federal Court decision of 12 October 1971). For details, see Brehm (fn 160) 325, 340 (at paras $72 \mathrm{f}$ ).

311 See Brehm (fn 97) art 46 no 14, 17; V Roberto, Schadensrecht (1997) 153 f. 
112 If tortious conduct leads to a person's death, the deceased's heirs are entitled to compensation for funeral expenses. If death was not immediate, the tortfeasor will also be liable for medical expenses and loss of earnings. Persons to whom the deceased provided support are entitled to compensation for loss of that support (Versorgerschaden/perte de soutien/ perdita del sostegno) (art $45 \mathrm{CO}) .312$

113 These general rules also apply in case of medical malpractice.

\section{Loss of earnings vs loss of earning capacity}

114 Compensation for temporary or permanent loss of earning capacity (Arbeitsunfähigkeit/incapacité de travail/impedimento al lavoro) is calculated on the basis of the injured person's actual or expected loss of income. A merely abstract loss of earning power is not indemnified. ${ }^{313}$

115 In the case of a permanent loss of earning capacity, the court may not simply consider the injured person's current income. Rather, it must make a projection as to how the injured person's career path and income would have developed if such person had not suffered any injury. This is especially difficult where the injured person is a young adult who has not yet embarked on a career, and even more so where children are concerned. 314

116 The Federal Court recently changed its case law by holding that compensation for loss of earnings must be calculated on the basis of the injured person's net (and not gross) income. ${ }^{315}$ The injured person's 'retirement damage' 316 is indemnified on the basis of such person's actual loss. Such loss is calculated by deducting the social insurance benefits that will actually be paid out to the injured person upon reaching old age from the hypothetical old-age benefits that such person would have received if he had not been injured. ${ }^{317}$

117 Where a homemaker has been injured, the Federal Court recognises an exception to the rule that only an actual or expected loss of income may be compensated. If the homemaker is unable to take care of the household

312 See, eg, Brehm (fn 160) 325, $346 \mathrm{ff}$ (at paras $95 \mathrm{ff}$ ).

313 See Brehm (fn 160) 325, 342 (at para 80); id (fn 97) art 46 no 35; Honsell (fn 174) $\$ 8$ no 67.

314 For details, see Brehm (fn 160) 325, 342-343 (at paras 81-84); see also Roberto (fn 143) paras $660 \mathrm{ff}$.

315 BGE $129 \mathrm{III}$ 135, $141 \mathrm{ff}$ (Federal Court decision of 19 December 2002).

316 See supra, no 110.

317 BGE 129 III 135, 150-151 (Federal Court decision of 19 December 2002). 
because of an injury, he will be entitled to compensation calculated on the basis of the average cost of home help, regardless of whether home help is actually employed or not (so-called 'household damage'; Haushaltschaden/ dommage ménager/danno della casalinga). ${ }^{318}$ Similarly, where the injured person worked gratuitously, eg in an effort to assist a spouse to establish or maintain a business venture, such person will also be entitled to compensation. ${ }^{319}$

\section{Periodic payments or lump sum?}

Pecuniary losses caused by bodily injury can be indemnified on a periodic basis or by lump sum. In general, it is in the court's discretion to decide whether indemnification shall be paid on a periodic basis or by capitalised (lump) sum. ${ }^{320}$

Until fairly recently, the constant practice of the Federal Court was that in the case of permanent damage, lump sum payment should be the rule rather than the exception. In 1999, however, it changed its position and decided that in principle, the injured person may choose between a lump sum or periodic payment. ${ }^{321}$

Costs incurred as a result of the tortious conduct are generally indemni120 fied by a lump sum..$^{322}$

\section{Caps and thresholds}

As a rule, there are no caps on the amounts available as compensation in Swiss law. An exception applies with respect to aviation liability under the Warsaw Convention. ${ }^{323}$ Likewise, there is no general minimum damage requirement.

318 See, eg, BGE 129 III 135, $151 \mathrm{ff}$ (Federal Court decision of 19 December 2002); BGE 127 III 403, 405 ff (Federal Court decision of 21 June 2001); BGE 132 III 321, 332 (Federal Court decision of 17 January 2006); Schwenzer (fn 234) para 14.10; Brehm (fn 160) 325, 341 (at para 79); Roberto (fn 143) para 732.

319 BGE 99 II 221, 224 (Federal Court decision of 26 June 1973).

320 Art 43(2) CO (fn 98). See BGE 125 III 312, 320 (Federal Court decision of 11 May 1999); Brehm (fn 97) art 43 no 7.

321 BGE 125 III 312, 320-321 (Federal Court decision of 11 May 1999). For details on capitalisation, see Brehm (fn 160) 325, $344 \mathrm{f}$ (at paras $90 \mathrm{f}$ ).

322 See, eg, Schnyder (fn 96) art 46 no 12.

323 See Brehm (fn 160) 325, 350 (at para 117). 
122 Both a cap and a minimum damage requirement are included in the Federal Act on Crime Victims Support. ${ }^{324}$ However, this Act does not establish or limit civil liability; rather, it aims to fill the gap where a crime victim and/or his relatives cannot otherwise receive compensation (eg because the offender is unknown or insolvent) ${ }^{325}$ by providing an entitlement against the Canton where the crime was perpetrated. Under the Act, compensation for pecuniary loss is capped at CHF 120,000, and the minimum required damage is CHF $500 .{ }^{326}$ Moreover, such compensation is only available to persons with modest income. ${ }^{327}$ Compensation for the victim's non-pecuniary loss is capped at $\mathrm{CHF} 70,000$, whereas the maximum compensation available to his relatives for their non-pecuniary loss is CHF $35,000.328$

123 Under the Swiss Product Liability Act, 329 the claimant must bear his own pecuniary loss up to an amount of CHF 900 . This sum will be deducted from his damages claim. At the same time, this provision works as a minimum damage requirement. However, it does not apply to losses sustained as a result of bodily injury. 330

\section{Non-pecuniary loss}

\section{Introduction to indemnifying non-pecuniary loss}

124 The main provisions on non-pecuniary loss are set forth in the Swiss Code of Obligations (CO). ${ }^{331}$ Compensation for non-pecuniary loss may also be available in the case of public liability; however, that is a matter of cantonal law. 332 The following paragraphs are confined to non-pecuniary loss under federal private law.

125 If a person has suffered bodily injury, the court may award him an appropriate sum for emotional distress (Genugtuung/réparation morale/ripa-

324 Federal Act on Crime Victims Support (CVSA) (Bundesgesetz über die Hilfe an Opfer von Straftaten [Opferhilfegesetz, OHG]) of 23 March 2007, SR 312.5.

325 Art 4(1) CVSA (fn 324).

326 Art 20(3) CVSA (fn 324).

327 Art 6(1) CVSA (fn 324).

328 Art 23(2) CVSA (fn 324).

329 See supra, no 72.

330 Art 6(1) PLA (fn 199).

331 Supra, fn 98.

332 On cantonal public law, see supra, nos $95 \mathrm{ff}$. 
razione), 'giving due consideration to the circumstances of the case' (art 47 CO). ${ }^{333}$ Compensation will usually be awarded if the claimant has suffered permanent damage which will cause physical discomfort or emotional distress for the rest of his life, although lesser injuries (such as an injury necessitating a long stay in hospital) may also qualify. ${ }^{334}$ Compensation is also available even if the victim is no longer able to appreciate his situation due to the injury, such as in the case of severe brain damage. ${ }^{335}$

If a person is killed, the court can award the victim's relatives an appropriate sum for emotional distress, again giving due consideration to the circumstances of the case (art $47 \mathrm{CO}$ ). 336

Compensation for non-pecuniary loss is also available if a person's personality rights are otherwise wrongfully infringed, on condition that such infringement is sufficiently serious to merit compensation and cannot otherwise be made good (art $49 \mathrm{CO}$ ). In particular, a victim's relatives may be entitled to compensation for the emotional distress caused them by the victim's injury. 337

Both under art 47 and art $49 \mathrm{CO}$, compensation for non-pecuniary loss is only available if the claimant has a cause of action in tort or in contract. 338 However, contractual claims are generally only available to the direct victim. As a rule, indirectly affected persons can only sue in tort. ${ }^{339}$

If more than one person owes the injured party compensation for nonpecuniary loss, the Federal Court has held that such persons will be jointly and severally liable. ${ }^{340}$

Compensation for non-pecuniary loss is determined on a case-to-case basis; there are no fixed standard rates. Rather, the court may determine the amount of compensation at its discretion. However, courts tend to follow the amounts awarded by other courts in previous decisions with

333 On the relevant criteria, see infra, no 130.

334 See, eg, Brehm (fn 160) 325, 349 (at para 110).

335 BGE 108 II 422, $431 \mathrm{ff}$ (Federal Court decision of 6 July 1982); for further references and a critique of the Federal Court's decisions, see Brehm (fn 97) art 47 no $21 \mathrm{ff}$.

336 See infra, no 135.

337 See infra, no 136.

338 See Schwenzer (fn 234) para 17.06; cf also BGE 123 III 204, 206-207 (Federal Court decision of 9 June 1997).

339 See infra, no 137.

340 See, eg, BGE 116 II 645, 650-651 (Federal Court decision of 9 October 1990). For a detailed discussion of this issue and further references to case law, see Brehm (fn 97) art 47 no 97 ff. 
similar facts. ${ }^{341}$ Criteria for assessing compensation are, in particular, the nature of the injury, the gravity, intensity and duration of its effects on the victim, the degree of the liable person's fault, whether the victim is partially at fault, and the chances that the award will alleviate the victim's emotional distress. ${ }^{342}$

131 The Federal Court recently held that non-pecuniary losses can also be indemnified on a periodic basis, although payment by lump sum is the rule. ${ }^{343}$

132 Swiss Courts are traditionally reluctant to award large sums for pain and suffering, although awards are getting larger. In recent years, the following sums have been awarded:

- in the case of severe disability: up to CHF 200,000;344

- in the case of death of a close relative: CHF 10,000-50,000 (depending on the closeness of the bond between victim and relative); 345

- in the case of severe disability of a close relative: CHF 20,000-50,000; the Federal Court has indicated that close relatives should receive approximately half of the amount awarded to the injured person himself. ${ }^{346}$

133 These general rules on non-pecuniary loss also apply in case of medical malpractice.

\section{Who can claim compensation for non-pecuniary loss?}

134 In the case of bodily injury, the direct victim may claim compensation for non-pecuniary loss under art 47 CO. 347

135 If the direct victim dies, the court may award the victim's 'relatives' compensation for emotional distress (art $47 \mathrm{CO}$ ). The term 'relatives' is

341 Courts often consult the table of court decisions provided by $\mathrm{K} \mathrm{Hütte} / \mathrm{P}$ Ducksch/K Guerrero, Die Genugtuung: eine tabellarische Übersicht über Gerichtsentscheide aus den Jahren 1990-2005 (3rd edn 2006).

342 BGE 132 II 117, 119 (Federal Court decision of 19 January 2006).

343 BGE $134 \mathrm{III}$ 97, $99 \mathrm{f}$ (Federal Court decision of 8 January 2008).

344 See M Sidler, Die Genugtuung und ihre Bemessung, in: Münch/Geiser (fn 97) 445, $468 \mathrm{ff}$ (at paras 10.54-55); Schwenzer (fn 234) para 17.14; Rey (fn 137) para 504; Brehm (fn 160) 325,354 (at para 132).

345 See Sidler (fn 344) 445, 476 ff (at para 10.66); Schwenzer (fn 234) para 17.14; Rey (fn 137) para 505.

346 See Sidler (fn 344) 445, 480 (at para 10.69); Schwenzer (fn 234) para 17.14 with further references.

347 On the requirements under art $47 \mathrm{CO}$, see supra, nos 125 and 130. 
misleading, as it is neither sufficient nor necessary for the claimant to be a member of the victim's family. Rather, the closeness of the bond between victim and claimant is decisive. Spouses, registered partners, parents and children of the victim will usually be entitled to compensation; fiancé(e)s and non-married partners may also qualify, as may brothers and sisters, grandparents and grandchildren etc as long as their bond with the deceased was sufficiently close. ${ }^{348}$ It is not necessary for these persons to have lived in the same household as the deceased.

If the victim is severely disabled, the victim's close relatives, such as parents, spouses and children, ${ }^{349}$ may also claim compensation in their own right on the basis of art $49 \mathrm{CO}$. However, such compensation is only granted if the victim's injury affects them at least as much as the victim's death would have. ${ }^{350}$ Although art $49 \mathrm{CO}$ could also serve as a basis for compensating other persons whose personality rights are infringed as a result of the victim's injuries, such claims have not yet been brought before the Federal Court.

As a rule, claims brought by a disabled victim's relatives under art $49 \mathrm{CO}$ or by a deceased victim's relatives under art $47 \mathrm{CO}$ can only be based in tort, not in contract. ${ }^{351}$ The practical consequence is that such claims will be subject to the shorter statute of limitations for tort suits. 352 The only exception is where the victim's relative himself contracted with the liable party, for example where the victim's legal guardian entered into a contract for the provision of medical services. ${ }^{353}$

\section{G. Procedural Matters}

\section{Specific rules of jurisdiction or procedure}

As pointed out above, procedural laws relating to public liability in

Switzerland are not federal, but cantonal, and until recently, the same

\footnotetext{
348 See Schwenzer (fn 234) para 17.09; Brehm (fn 97) art 47 no 133 ff.

349 See BGE 116 II 519, 520-521 (Federal Court decision of 23 October 1990). For further references to case law, see Brehm (fn 97) art 49 no $67 \mathrm{f}$.

350 BGE 123 III 204, 206 (Federal Court decision of 9 June 1997).

351 See supra, no 86.

352 Cf supra, no 83. For an example from case law, see BGE 123 III 204, $206 \mathrm{ff}$ (Federal Court decision of 9 June 1997).

353 Cf supra, no 87. For an example from case law, see BGE 116 II 519, 520-521 (Federal Court decision of 23 October 1990). See also Case 1, infra, nos $151 \mathrm{ff}$.
} 
was also true with respect to civil procedure. ${ }^{354}$ It is beyond the scope of this report to give details on the procedural laws of each of the 26 Cantons. Generally, however, medical malpractice cases will not be treated differently to other cases under cantonal procedural laws, and the same applies under the Federal Act on Civil Procedure.

139 If claims are brought under federal private law, jurisdiction will lie with the ordinary civil courts of the Cantons. ${ }^{355}$ The place of jurisdiction is determined by federal law, ${ }^{356}$ which does not set forth any special rules regarding medical malpractice.

140 If public liability is at issue, claims will often also fall within the jurisdiction of the ordinary civil law courts; however, this is a matter of cantonal law. ${ }^{357}$

\section{Special institutions handling malpractice claims}

141 If a patient suffers injury in the course of medical treatment and suspects that he is a victim of medical malpractice, he (or his successor) may contact the Swiss Medical Association (FMH) before going to court. The FMH operates a special 'Out-of-Court Expert Report Office' (aussergerichtliche Gutachterstelle/Bureau d'expertises extra-judiciaires).

142 The proceedings before the Office are governed by a regulation passed by the FMH. ${ }^{358}$ All FMH-members must submit to, and cooperate in, proceedings before the Office. ${ }^{359}$ If a member refuses to cooperate, he will be subject to the disciplinary sanctions under the FMH's rules of professional conduct. ${ }^{360}$

143 As the FMH is a private organisation, its regulations are only binding on its members. As soon as other persons (eg non-members, hospitals, or a Canton) might be liable, be it exclusively or together with a member of the FMH, the Office will not act unless such persons agree to submit to the proceedings. ${ }^{361}$

\footnotetext{
354 See supra, nos 8 and 103.

355 See Guillod (fn 87) 392, 413 (at para 83).

356 See the Federal Act on Civil Procedure (fn 18), which includes jurisdictional rules in its arts $9 \mathrm{ff}$.

357 See supra, no 103.

358 Regulation on the FMH-Office for Out-of-Court Expert Reports on Medical Liability (Reglement für die FMH-Gutachterstelle zur aussergerichtlichen Begutachtung von Ärztehaftpflichtfällen) of 1 February 2002, available at <http://www.fmh.ch/files/pdf1/Reglement_D.pdf $>$ (12.01.11).

359 Art 2 of the Regulation (fn 358).

360 On these rules, see supra, no 38.

361 Art 3 of the Regulation (fn 358).
} 
The Office will only commission an expert report on the patient's case if certain requirements are met. ${ }^{362}$ In particular, the alleged mistake must have caused considerable injury to the applicant. The Office will not accept a patient's application for an expert report if a court case is pending.

The subject-matter of the expert reports commissioned by the Office is limited. The designated expert(s) must first assess whether the doctor breached any duty of care with respect to diagnosis or treatment. If this is answered in the affirmative, the expert(s) must also assess the consequences of the breach for the patient's health (issue of causation). ${ }^{363}$ The parties are not legally bound to accept the expert's conclusions, ${ }^{364}$ although the doctor concerned (and the liability insurer, who is also involved in the proceedings) usually does so. ${ }^{365}$

In all cases, the applicant must pay administrative charges of CHF 600 (plus VAT). In certain circumstances, the Office may request an additional CHF 2,000 as security from the applicant, in particular if there is only a small likelihood of a mistake in diagnosis or treatment. ${ }^{366}$

From 1982 to 2009, 3233 expert reports were made under the Office's supervision. ${ }^{367}$ A mistake in treatment or diagnosis was confirmed in 1065 cases (32.9\%), denied in 2075 cases (64.2\%), and left undecided in the remaining 93 cases (2.9\%). The majority of alleged mistakes occurred in surgery (804 reports made, 278 mistakes confirmed), orthopaedic surgery (596 reports made, 211 mistakes confirmed), and gynaecology/obstetrics (395 reports made, 151 mistakes confirmed). ${ }^{368}$

\section{H. Outlook}

\section{Reform plans}

There are currently no comprehensive reform plans relating to medical liability in Switzerland. Although the preliminary draft law on tort reform

362 See art 5 of the Regulation (fn 358).

363 Art 13(1) of the Regulation (fn 358).

364 Art 14(2) of the Regulation (fn 358).

365 See Guillod (fn 87) 392, 414 (at para 87 in fine).

366 Art 9 of the Regulation (fn 358).

367 The Office's annual reports are available at $<\mathrm{http}: / /$ www.fmh.ch/service/gutachterstelle/jahresberichte.html $>$ (12.01.11).

368 L Rabia/N Favre, Annual Report of the FMH-Office 2009 (Aussergerichtliche FMH-Gutachterstelle - Jahresbericht 2009), SÄZ No 30-31/2010, $1131 \mathrm{ff}$. 
included several provisions which would have had an impact on various aspects of medical liability, ${ }^{369}$ this project has now been abandoned by the Federal Council. ${ }^{370}$ The only remaining item on the tort reform agenda is the extension of the general limitation period for tort claims. ${ }^{371}$

149 Nonetheless, issues relating to selected areas of medical activity are being discussed. Thus, the draft Federal Act on Human Research ${ }^{372}$ provides that persons or institutions that have initiated human research projects shall be strictly liable for any damage suffered by human research subjects, although the Federal Council may provide for exceptions. ${ }^{373}$ Strict liability under the draft covers compensation for bodily injury, property damage, and harm caused to the subject's personality rights. Both pecuniary and non-pecuniary losses are covered. ${ }^{374}$ Claims are subject to a limitation period of three years from the day the harmed person acquired knowledge of the damage and the liable party's identity. In any event, the maximum limitation period is ten years from the day the research project was completed. The Federal Council may provide longer limitation periods for particular research areas. ${ }^{375}$ The potentially liable party must take out liability insurance or provide other, equivalent security. ${ }^{376}$

150 Another item on the political agenda relating to health issues is the draft Federal Act on Prevention and Health Promotion. ${ }^{377}$ However, this draft does not include any provisions on medical liability.

369 See $P$ Wessner, La révision totale du droit de la responsabilité civile: quelques orientations nouvelles susceptibles d'influencer le domaine des soins médicaux et hospitaliers, Le responsabilité médicale (1996) $57 \mathrm{ff}$.

370 See the Federal Council's press release of 21 January 2009, supra fn 148.

371 See supra, no 53.

372 Entwurf eines Bundesgesetzes über die Forschung am Menschen (Humanforschungsgesetz, HFG) of 21 October 2009, available at <http://www.admin.ch/ch/d/ff/2009/8163.pdf $>$ (12.01.11). Art 19(1) of the draft (fn 372).

374 Message of the Federal Council concerning the Federal Act on Human Research (Botschaft zum Bundesgesetz über die Forschung am Menschen) of 21 October 2009, Bundesblatt 2009, 8045, 8109, available at <http://www.admin.ch/ch/d/ff/2009/8045.pdf $>$ (12.01.11). Art 19(2) of the draft (fn 372).

376 Art 20 of the draft (fn 372).

377 Entwurf eines Bundesgesetzes über Prävention und Gesundheitsförderung (Präventionsgesetz, PrävG) of 30 September 2009, available at <http:/www.admin.ch/ch/d/ff/2009/ 7189.pdf $>$ (12.01.11). The Message of the Federal Council is available at $<\mathrm{http}: / /$ www.admin.ch/ch/d/ff/2009/7071.pdf $>$ (12.01.11). 


\section{Cases}

\section{Case 1}

The following analysis is based on the assumption that the hospital run by $\mathrm{C}$ is a private hospital, subject to federal private law. ${ }^{378}$ From the facts of the case, one can assume that both $\mathrm{A}$ and $\mathrm{D}$ made a mistake during treatment.

As the newborn $\mathrm{Y}$ does not have a contract with either A, B, or C, she will not be able to sue any of them in contract - at least not under traditional rules. ${ }^{379} \mathrm{Y}$ might sue in tort instead, but will in any case face several difficulties.

A might be liable for Y's pecuniary loss under art 41(1) $\mathrm{CO}^{380}$ and for Y's non-pecuniary loss under art 47 CO. ${ }^{381}$ However, Y's claims will only succeed if she can prove that A's conduct was a conditio sine qua non of her condition. The burden of proof with regard to causation lies with $\mathrm{Y}$, even if A's conduct qualifies as a grave mistake. $Y$ will have to show that A's mistake more likely than not caused, in whole or in part, the damage suffered. A will not be liable if it is merely possible that his conduct caused Y's injury in whole or in part. 382

The issue of causation will also arise if $\mathrm{Y}$ sues B or C in tort. Moreover, as B himself did not make any mistake, he might only be liable for Y's pecuniary and non-pecuniary loss if either A or D's conduct could be imputed to him under art 55(1) CO. ${ }^{383}$ However, neither A (with whom B shares a joint practice) nor D (who is employed by $\mathrm{C}$ ) is subject to B's supervision and authority to issue directives. ${ }^{384}$ Accordingly, B cannot be held responsible toward Y for either A or D's conduct.

Likewise, A's conduct cannot be imputed to C under art 55(1) CO, as A is an affiliated doctor and therefore not subordinate to C. ${ }^{385}$ In contrast, as midwife $\mathrm{D}$ is employed by $\mathrm{C}$, her conduct will generally be imputed to $\mathrm{C}$

378 Cf supra, no 45.

379 The concept of contracts with protective effect for third parties has not hitherto been recognised in Swiss law (see supra, no 88). However, a lawyer representing Y might argue that the contracts entered into by Y's mother were also concluded for the benefit of her unborn child, so that $\mathrm{Y}$, once she was born, could base her claim in contract (see supra, no 87). This line of argument has not yet been brought before the Federal Court. On the requirements under art 41(1) CO, cf supra, no 47. On liability for non-pecuniary loss, cf supra, nos $124 \mathrm{ff}$.

Cf supra, no 56.

On the requirements under art 55(1) CO, see supra, nos $48 \mathrm{ff}$.

On the requirement of subordination, see supra, no 48 .

Cf supra, no 68. 
(and not to A), unless her mistake occurred whilst she was de facto subject to A's supervision and authority to issue directives. ${ }^{386}$ Accordingly, C might be liable for Y's pecuniary and non-pecuniary loss if the further requirements of art 55(1) CO are met. C could avoid liability by proving that he took all precautions necessary to prevent damage of the kind suffered. ${ }^{387}$ However, the central issue in a claim against $\mathrm{C}$ will be that of causation: $Y$ will have to prove that her injury was caused, in whole or in part, by D's tortious conduct. 388

156 If $Y$ succeeds in proving causation both with respect to $A$ and $D$, and if $C$ is unable to prove that all necessary precautionary measures were taken, A and $\mathrm{C}$ will be jointly and severally liable toward $\mathrm{Y}$ for any pecuniary loss suffered by $\mathrm{Y}$ which is not too remote (art $51 \mathrm{CO}$ ). ${ }^{389}$ Such compensation would also, in principle, cover the costs of day care by professional nursing staff, even if the associated costs are greater than if $Y$ lived in a nursing home. Although the injured party must take all reasonable steps to mitigate the loss, he is not required to take the least expensive option. Rather, if a certain measure is necessary or at least beneficial to the injured party and also appropriate from a medical standpoint, the ensuing costs should be compensated. ${ }^{390}$ However, this issue has not hitherto been raised before the Federal Court.

157 If $\mathrm{Y}$ succeeds in proving causation, she will also be entitled to claim compensation for the care provided by $\mathrm{X}$, on the basis of the average cost of home care. ${ }^{391}$ Due to the gravity of the injury, ${ }^{392} \mathrm{Y}$ would also receive compensation for non-pecuniary loss under art $47 \mathrm{CO}$. If a cause of action is maintainable against both $\mathrm{A}$ and $\mathrm{C}$, they will again be jointly and severally liable. ${ }^{393}$

158 Unlike $\mathrm{Y}, \mathrm{X}$ entered into a contract with $\mathrm{B}$ and, once she was admitted to C's hospital, also into a contract with C. X's contract with $C$ will be classified as a 'fractioned hospital contract'. ${ }^{394}$ Accordingly, both B and $\mathrm{C}$ may be liable toward X in contract under art 97(1) CO. 395

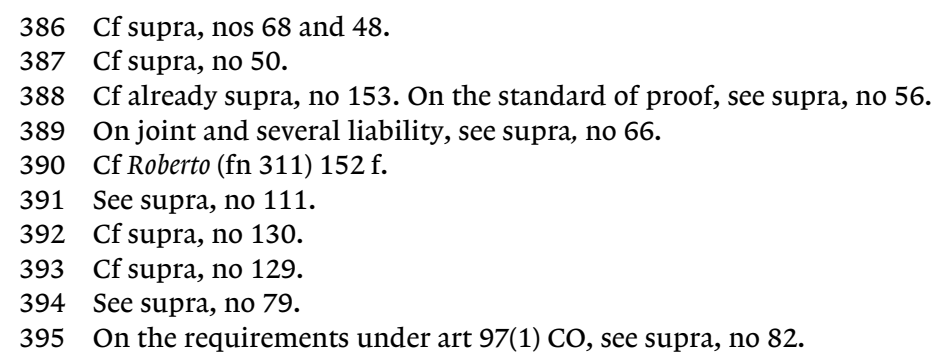


As B's locum, A will be considered B's auxiliary under art 101(1) CO,396 so that A's acts or omissions will be imputed to B for the purposes of liability. Midwife D will be considered either C's or B's auxiliary, depending on whether the taking of a CTG fell within C's or B's contractual responsibilities. ${ }^{397}$ In any case, however, the central problem for X will also be the issue of causation, which she must prove. With respect to B's liability, $\mathrm{X}$ must show that A's mistake more likely than not caused, in whole or in part, her pecuniary loss. Likewise, if D is qualified as C's auxiliary, C will only be liable for X's pecuniary loss if D's mistake more likely than not caused such loss, in whole or in part. 398

If $X$ succeeded in proving causation both with respect to A and D's conduct, $\mathrm{B}$ and $\mathrm{C}$ would be jointly and severally liable toward $\mathrm{X}$ for her pecuniary loss (art $51 \mathrm{CO}$ ). ${ }^{399}$ It is probable that Swiss Courts would award $\mathrm{X}$ compensation for the care that she herself is providing to $\mathrm{Y}$ on the basis of the average cost of home care. It would not be necessary for X to suffer actual pecuniary loss (eg by giving up her job). However, the Federal Court has hitherto only had occasion to discuss such claims brought by the injured party himself. 400

Due to the gravity of the injury, $\mathrm{X}$ would also be entitled to compensation for non-pecuniary loss under art $49 \mathrm{CO} .401$ If a cause of action were maintainable against both $\mathrm{B}$ and $\mathrm{C}$, they would be jointly and severally liable for such loss. ${ }^{402}$ This would also apply with respect to the stillbirth of X's son, if X were able to prove that such stillbirth was caused by A and D's mistakes.

As $\mathrm{X}$ did not enter into a contract with $\mathrm{A}$, any claims against $\mathrm{A}$ would be in tort (art 41[1] CO). Here, as before, the main issue will be that of causation. Additionally, the question will arise as to whether A's conduct toward $\mathrm{X}$ can be classified as wrongful under art 41(1) CO. X seeks an award of compensation for the care that she herself is providing to $\mathrm{Y}$. Such damage constitutes pure economic loss, for which compensation is only available if a 'protective norm' (Schutznorm/norme de protection/norma protettiva) has been breached. The same problem would also arise if $\mathrm{X}$ were to sue $\mathrm{B}$ and/or $\mathrm{C}$

396 On art 101(1) CO, see supra, no 85.

397 Cf supra, no 79.

398 On the burden of proof with regard to causation, see supra, no 56.

399 On joint and several liability, see supra, no 66.

400 Cf supra, nos 111 and 157.

401 Cf supra, no 136.

402 See supra, no 129. 
in tort rather than in contract, although given the advantages of contract claims, ${ }^{403}$ she would be unlikely to do so.

\section{Case 2}

163 The Federal Court decided the controversial issue of 'wrongful conception' in favour of the child's parents in $2005 .{ }^{404}$ In that case, the claimant was to undergo a Caesarean section with her second child and had requested that she be sterilised at the same time. The claimant and her husband had decided on sterilisation for economic reasons. However, the hospital negligently omitted to perform the sterilisation. Unaware of the mistake, the claimant soon after became pregnant and subsequently gave birth to her third child. The claimant's husband assigned his contractual rights to the claimant, who then successfully sued the hospital. She was granted compensation for pecuniary loss, including child maintenance costs, by the cantonal courts, as well as compensation for non-pecuniary loss. The cantonal decision was confirmed by the Federal Court.

164 As a result of the Federal Court's decision, it is safe to assume that in principle, A will be liable in contract toward $X$ for any pecuniary loss sustained as a result of the birth of her son $\mathrm{Z}$, including child maintenance costs throughout the child's minority and loss of earnings, on condition that A breached his contractual obligations toward X (art 97[1] CO).405 However, one important difference between the Federal Court decision and Case 2 is that in Case 2, it is not clear whether $\mathrm{X}$ had decided against having children once and for all, or only for the time-being. This issue of 'timing' was not raised before the Federal Court, and even if it had been, it would probably not have made any difference as the claimant and her husband already had two children. The situation is different with respect to X; although her choice of contraception indicates that she had no wish to become pregnant in the near future, it is not clear whether she had decided against having children once and for all. It has been suggested that where a woman has only decided against having children at a certain moment in time, only the pecuniary loss resulting from the premature birth of a child may be compensated. ${ }^{406}$ However, one might object that it will usually be impossible to prove whether the woman in question has

\footnotetext{
403 See supra, nos $83 \mathrm{ff}$.

404 BGE 132 III 359 ff (Federal Court decision of 20 December 2005).

405 On the requirements under art 97(1) CO, see supra, no 82.

406 See Roberto (fn 143) para 768.
} 
reached a final decision or not, nor can anyone (including the woman herself) know whether she might have changed her mind in the future. It remains to be seen how the Federal Court would decide this issue.

It might also be possible for $\mathrm{X}$ to bring a claim in tort under art 41(1) $\mathrm{CO},{ }^{407}$ although this issue has not yet been raised before the Federal Court (and is unlikely to be, unless the claimant is unable to sue in contract). 408 In a tort claim against $\mathrm{A}$, the central issue would be whether A's conduct qualifies as wrongful for the purposes of art 41(1) CO. This would probably be answered in the affirmative, as X's personality rights (namely her autonomy of decision) have been infringed. 409

The matter is more complex with respect to Z's father, Y. As the concept of contracts with protective effect for third parties has not hitherto been recognised in Swiss law, ${ }^{410} \mathrm{Y}$ would only be able to sue in contract if he was also a party to the contract between $\mathrm{A}$ and $\mathrm{X}$. However, it might be possible for $Y$ to bring a claim against $A$ in tort under art 41(1) CO. The central issue in such a claim would be whether A's conduct can be considered wrongful with regard to $\mathrm{Y}$. This issue has not yet been raised before the Federal Court, but might be answered in the affirmative based on Y's personality rights. ${ }^{411}$

\section{Case 3}

The following analysis is based on the assumption that both the hospital run by $\mathrm{A}$ and the clinic run by $\mathrm{C}$ are private hospitals, subject to federal private law. 412

As $\mathrm{X}$ himself did not enter into a contract with $\mathrm{A}$, any claims by $\mathrm{X}$ against $\mathrm{A}$ would be be based in tort, at least under traditional rules. ${ }^{413}$ It is probable that such a claim would succeed, both with respect to X's pecuniary loss under art 55(1) $\mathrm{CO}^{414}$ and his non-pecuniary loss under art $47 \mathrm{CO} .{ }^{415}$ The obstetrician's failure to seek the advice of a paediatrician and the failure to

407 On the requirements under art 41(1) CO, cf supra, no 47.

408 See also Roberto (fn 143) para 486. On the advantages of contract claims over tort claims, see supra, nos $83 \mathrm{ff}$.

409 Cf Roberto (fn 143) para 486.

410 See supra, no 88.

411 Cf supra, no 165, with regard to $\mathrm{X}$.

412 Cf supra, no 45.

413 Cf supra, no 152 with fn 379.

414 On the requirements under art 55(1) CO, see supra, nos $48 \mathrm{ff}$.

415 On liability for non-pecuniary loss, cf supra, nos $124 \mathrm{ff}$. 
inform X's mother and the midwife of the necessity to monitor X's blood sugar levels would be imputed to A under art 55(1) CO. Although it is recognised in Swiss law that the link between original cause and effect may be interrupted by subsequent events (Unterbrechnung des Kausalzusammenhangs/interruption de la causalité/interruzione della causalità) ${ }^{416}$ with the result that the original cause will be considered too remote, it is unlikely that this would help A to avoid liability. Such an 'interruption' is admitted only rarely by Swiss courts, as it means taking an 'all or nothing' approach to liability. ${ }^{417}$ Moreover, had X been treated properly in A's hospital, midwife $B$ and the clinic $C$ would not actually have had the 'opportunity' to contribute to X's injuries. It is also unlikely that A would succeed in showing that it exercised all due diligence in selecting, instructing and overseeing the obstetrician.

169 With respect to midwife $B$, it is probable that she would be held liable toward X not only in tort under art 41(1) CO,418 but also in contract under art $97(1)$ CO, ${ }^{419}$ as X's mother entered into the contract with B for X's benefit. ${ }^{420}$ However, midwife B will in any case only be liable toward X if her conduct was a conditio sine qua non of X's injuries, which $\mathrm{X}$ will have to prove. It is sufficient, but also necessary, that X's injuries would probably have been avoided if $B$ had sought the advice of a paediatrician. ${ }^{421}$ If such proof is provided, B will also be liable for X's non-pecuniary loss, on the basis of art $47 \mathrm{CO}$ in conjunction with art 41(1) and art 97(1) CO, respectively.

$170 \mathrm{C}$ will likely also be held liable toward $\mathrm{X}$ in contract under art 97(1) CO, as X's parents entered into a contract with C for X's benefit. ${ }^{422}$ The failure to provide $\mathrm{X}$ with adequate care on time due to organisational deficiencies qualifies as a breach of C's contractual duties toward $\mathrm{X}$, and as $\mathrm{C}$ will be considered responsible for ensuring that the clinic is organised satisfactorily, $\mathrm{C}$ will not succeed in showing that it bore no fault. Also, E's conduct will be imputed to $C$ on the basis of art 101(1) CO. ${ }^{423}$ As it can be assumed with a very high degree of probability that X's injuries were sustained in C's clinic, the requirement of causation is also fulfilled. Accordingly, C

\footnotetext{
416 See, eg, Rey (fn 137) paras $551 \mathrm{ff}$.

417 See, eg, Werro (fn 174) para 223.

418 On the requirements under art 41(1) CO, cf supra, no 47.

419 On the requirements under art 97(1) CO, see supra, no 82.

420 Cf supra, no 87.

421 Cf supra, no 56.

422 Cf supra, no 87.

423 On art 101(1) CO, see supra, no 85.
} 
will be liable for X's pecuniary loss, as well as for X's non-pecuniary loss under art 97(1) in conjunction with art $47 \mathrm{CO}$.

$\mathrm{C}$ could also be held liable for X's pecuniary and non-pecuniary loss on the basis of art 55(1) CO. Although a contractual claim will be more advantageous, ${ }^{424} \mathrm{X}$ is free to choose whether to sue $\mathrm{C}$ in contract or in tort. As $\mathrm{E}$ is subordinated to $C$, her conduct would be imputed to $C$ under art 55(1) CO. $\mathrm{C}$ would not succeed in showing that it had exercised all due diligence in selecting, instructing and overseeing her, as E had not been instructed to take and record a detailed case history, nor to call an experienced doctor within a reasonable period of time.

On condition that E's conduct constituted a conditio sine qua non of X's damage (which $\mathrm{X}$ has to prove), $\mathrm{E}$ will be liable toward $\mathrm{X}$ in tort under art 41(1) CO. Her lack of experience will not serve to exonerate her, as she should at least have recognised that she lacked the experience to correctly assess X's state and called on an experienced doctor when she saw the alarming results of the first test. She will also be held liable for X's nonpecuniary loss under art 41(1) in conjunction with art $47 \mathrm{CO}$.

Liability of A, B, C, and E will be joint and several (art 51 CO). ${ }^{425}$ Compensation for X's pecuniary loss will cover the costs of nursing care and the expenses caused by X's increased needs (art 46 CO). ${ }^{426}$ With respect to X's loss of earning capacity, the court will make a projection as to how X's career path and income would have developed without the sustained injuries. Swiss courts tend to base such projections on the careers chosen by the victim's family members. In case of very young victims, courts tend to be conservative when assessing loss of future earnings. $427 \mathrm{X}$ may choose between compensation by lump sum and periodic payment. ${ }^{428}$ Damages will be calculated on the basis of X's estimated future net income. In addition, $\mathrm{X}$ will be entitled to compensation for his 'retirement damage'. ${ }^{429}$ Given the grave nature of X's injuries, A, B, C, and E will also liable for X's non-pecuniary loss (art $47 \mathrm{CO}$ ). Such liability will be joint and several. 430

424 On the advantages of contract claims over tort claims, see supra, nos $83 \mathrm{ff}$.

425 Cf supra, nos 66, 78.

426 For details on calculating such costs, see the case discussion by Brehm (fn 160) 325, 359 (at paras $158 \mathrm{ff}$ ).

427 See Brehm (fn 160) 325, $342 \mathrm{f}$ (at paras 83, 84).

428 See supra, no 119.

429 See supra, nos 110 and 116.

430 See supra, no 129. 


\section{Case 4}

174 The following analysis is based on the assumption that the A clinic is a private hospital, subject to federal private law, 431 and that $\mathrm{X}$ had a contract only with the A clinic ('comprehensive hospital contract'). ${ }^{432}$

$175 \mathrm{X}$ was not properly informed of the risks involved with the proposed operation. Firstly, there was no interpreter present during the consultation, although X could only speak Persian (and B could not). Accordingly, B's information did not put $\mathrm{X}$ in a position to reach a well-considered decision about the suggested procedure. ${ }^{433}$ Secondly, $\mathrm{X}$ was not informed of the different types of procedure available (transthoracic opening versus dorsal approach) and the different risks involved. And finally, $\mathrm{X}$ was informed only one day prior to the operation. Given the nature of the operation and the risks involved, this was too late. ${ }^{434}$ It is for the A clinic to prove that $\mathrm{X}$ gave his informed consent to the proposed operation. ${ }^{435}$

176 As the A clinic has not satisfied the legal requirements of informed consent, it will be liable in contract under art 97(1) $\mathrm{CO}^{436}$ for all damage suffered by $\mathrm{X}$ as a result of the operation, regardless of whether such damage was caused by a mistake in treatment or simply by chance, as long as such damage is not too remote. ${ }^{437} \mathrm{~B}$ 's failure to properly inform $\mathrm{X}$ will be imputed to the A clinic under art 101(1) CO.438 The A clinic will not succeed in showing that $\mathrm{X}$ would have consented to the intervention even if he had been properly informed. The test for such 'hypothetical consent'439 is not whether a 'reasonable' patient, but whether the individual patient would have consented to the intervention. According to the facts of the case, $X$ would probably not have had surgery at all if he had been properly informed, and his condition would not necessarily have deteriorated without the operation.

177 Accordingly, the A clinic will be liable in contract toward $\mathrm{X}$ for the pecuniary loss caused by the operation, as long as such loss is not too remote. Compensation will include the costs of converting X's house to

\footnotetext{
431 Cf supra, no 45.

432 On comprehensive hospital contracts, see supra, no 78.

433 Cf Fellmann (fn 111) 103, 196.

434 Cf supra, no 92.

435 Cf supra, no 89.

436 On the requirements under art 97(1) CO, see supra, no 82.

437 Cf supra, no 90.

438 Cf supra, no 85.

439 See supra, no 90.
} 
provide wheelchair access. In contrast, the costs of a new car with wheelchair access will only be compensated if $\mathrm{X}$ is still able to work and needs an automobile for that purpose. ${ }^{440} \mathrm{X}$ will also be entitled to compensation for non-pecuniary loss under art $47 \mathrm{CO}$, given the grave consequences of the intervention. 441

$\mathrm{X}$ could also claim compensation for pecuniary and non-pecuniary loss from the A clinic in tort (art 55[1] CO), as B, the doctor who (inadequately) informed X, is subordinated to A. ${ }^{442}$ It is unlikely that A would succeed in showing that it exercised all due diligence in selecting, instructing and overseeing B. As in contract, it would be for the A clinic to prove that $\mathrm{X}$ gave his informed consent to the operation. ${ }^{443}$ However, contractual liability is more advantageous for X. ${ }^{444}$

As $\mathrm{X}$ did not enter into a contract with surgeon $\mathrm{C}, 445 \mathrm{C}$ might only be liable toward $\mathrm{X}$ in tort (art 41[1] CO), 446 which is less attractive for $\mathrm{X}$ than suing the A clinic in contract. $\mathrm{C}$ will be liable in tort if he was under an individual duty to inform $\mathrm{X}$ prior to the operation. The Federal Court has not hitherto had to determine with whom precisely the duty to inform lies in the case of hospitalisation, as injured patients generally sue the hospital itself (and not the individual doctor). In general, the doctor who is to perform the procedure is under a duty to inform the patient of the risks involved. The prevailing opinion in Switzerland is that a doctor may delegate his duty to inform to another doctor, except where such other doctor does not have sufficient knowledge of the case or is not sufficiently qualified. In any case, the delegating doctor must ascertain whether the patient has been sufficiently informed before he carries out the procedure. ${ }^{447}$ It follows that in Case 4 , surgeon $C$ was at the very least under a duty to make sure that $\mathrm{X}$ had been properly informed by $\mathrm{B}$ before the operation. It is for $\mathrm{C}$ to prove that he complied with this duty, ${ }^{448}$ but as the facts of the case show that $\mathrm{X}$ was not properly informed, $\mathrm{C}$ will not succeed. Accordingly, $\mathrm{C}$ will be liable toward $\mathrm{X}$ in tort for the same items of damage as the A clinic and also for non-pecuniary loss under art 47

440 Cf Brehm (fn 97) art 46 no 24, with references to case law.

441 On liability for non-pecuniary loss, cf supra, nos $124 \mathrm{ff}$.

442 On the requirements under art 55(1) CO, cf supra, nos $48 \mathrm{ff}$.

443 Cf supra, no 89.

444 Cf supra, nos $83 \mathrm{ff}$.

445 Cf supra, no 174.

446 On the requirements under art 41(1) CO, cf supra, no 47.

447 See Fellmann (fn 111) 103, 194; Wiegand (fn 272) 119, 149 f.

448 Cf supra, no 89. 
CO. ${ }^{449}$ Liability of $\mathrm{C}$ and the A clinic will be joint and several, both with regard to compensation for pecuniary and non-pecuniary loss. 450

180 A and $C$ might object that sooner or later, $X$ would have suffered the same damage anyway, as $\mathrm{X}$ was already suffering from myelopathy with paralysis symptoms when he was operated on. It is not clear to what extent such an objection might be heard in Swiss law. ${ }^{451}$ In any case, the success of such an objection would depend on the likelihood that damage would have occurred regardless of the operation at a later point in time.

\section{Case 5}

181 As before, the following analysis is based on the assumption that the hospital run by $\mathrm{A}$ is a private hospital, subject to federal private law,452 and that X had a contract only with A ('comprehensive hospital contract').453

182 A might be liable toward $X$ in contract under art 97(1) CO.454 In principle, the acts and omissions of A's employees B, C, and D during the operation will be imputed to A under art 101(1) CO.455 However, X will have to prove that $\mathrm{B}, \mathrm{C}$, and/or $\mathrm{D}$ made a mistake which constitutes a breach of the contract between $\mathrm{A}$ and $\mathrm{X}$, and that such a breach caused his damage. The mere fact that $\mathrm{X}$ suffered injury is not sufficient to infer medical malpractice. Nor is it recognised in Swiss law that the hospital and responsible doctors bear the burden of proof with regard to the correct positioning of a patient during an operation. 456

183 With respect to A's liability, two hypotheses are imaginable. Under the first hypothesis, not even the slightest risk of damage to the nervus ulnaris is inherent in this type of operation. If this hypothesis is correct, the damage suffered by $\mathrm{X}$ will necessarily imply that his injury was caused by a mistake made during the operation, so that $\mathrm{A}$ will be liable in contract.

449 Cf supra, no 177.

450 Cf supra, nos 78 and 129.

451 See, eg, Schwenzer (fn 234) para 21.05 with further references.

452 Cf supra, no 45.

453 On comprehensive hospital contracts, see supra, no 78.

454 On the requirements under art 97(1) CO, see supra, no 82.

455 Cf supra, no 78.

456 The Federal Court has not yet been called on to decide this issue. See also Kuhn (fn 154) $601,653 \mathrm{ff}$. 
Under the second hypothesis, damage to the nervus ulnaris is an inherent risk of this type of operation. If this hypothesis is correct, $\mathrm{X}$ will be welladvised to allege that he was not properly informed of this risk, as A will have to prove that $\mathrm{X}$ gave informed consent. If the legal requirements of informed consent are not satisfied, A will be liable in contract for all damage suffered by $\mathrm{X}$ as a result of the operation, as long as such damage is not too remote. A may only avoid liability if A can show that X would have consented to the operation even if he had been properly informed (hypothetical consent). ${ }^{457}$

If A succeeds in proving that $\mathrm{X}$ was sufficiently informed of the risks, or that $\mathrm{X}$ would have consented anyway, $\mathrm{X}$ will be required to prove that a mistake was made during the operation. According to the facts of the case, it cannot be ascertained whether surgeon B positioned X's arm improperly, as the clinical records are incomplete. Nor can it be ascertained whether anaesthetist $\mathrm{C}$ monitored the proper positioning of X's arm during the operation. It is uncertain in Swiss law whether the burden of proof might be shifted to A because the records are incomplete, although at the very least, the standard of proof might be relaxed. ${ }^{458}$ With respect to the issue of monitoring, $\mathrm{C}$ will be required to cooperate in the evidentiary proceedings before the court. Whether or not a court will be satisfied that $B$ and/or $C$ made a mistake during the operation cannot be said in the abstract; rather, this will depend on the court's appreciation of the evidence. If the court is satisfied that B and/or C made a mistake, it will suffice for $\mathrm{X}$ to show that such mistake more likely than not caused his injury.459 Whether or not he is successful will depend on how large the inherent risk of damage to the nervus ulnaris is.

By itself, the fact that $\mathrm{C}$ was not supervised more closely by $\mathrm{D}$ is not

sufficient to hold A liable toward X. If $C$ was not supervised sufficiently under current professional standards, this will constitute a breach of contract by A. However, $\mathrm{X}$ will still have to prove that such breach more likely than not caused his damage. 460 This will be difficult to prove unless the court is satisfied that $\mathrm{C}$ did not monitor the position of X's arm correctly.

457 Cf supra, no 90.

458 Cf supra, no 58.

459 Cf supra, no 56.

460 Cf supra, no 56. 
$187 \mathrm{X}$ might also choose to sue A in tort on the basis of art 55(1) CO,461 as B, C, and $\mathrm{D}$ are all subordinated to A. However, apart from the fact that tort claims are less advantageous to the claimant, $462 \mathrm{X}$ will still be faced with the problem of proving that a mistake was made which caused his damage. As in contract, the situation will change for X's benefit if he was not properly informed of the risks inherent in the operation, 463 or if no risk at all of damage to the nervus ulnaris is inherent in this type of operation. ${ }^{464}$

188 As far as the liability of B, C, and D is concerned, the same problems of proof arise as with respect to $\mathrm{A}$, ie as to the questions of mistake and causation. Again, the situation will change if $\mathrm{X}$ did not give his informed consent or the risk of damage to the nervus ulnaris is not inherent in this type of operation. In any case, B, C, and D might only be liable toward $\mathrm{X}$ in tort (art 41[1] CO). 465

189 If liability of $\mathrm{A}, \mathrm{B}, \mathrm{C}$, or $\mathrm{D}$ were accepted, $\mathrm{X}$ would receive compensation for loss of earnings, as he is no longer able to work as a bricklayer. $\mathrm{X}$ would also be entitled to compensation for loss of earnings from his weekend job. However, if $\mathrm{X}$ can reasonably be expected to retrain, for example as a sales person in a building supplies store, the wages $X$ would earn in such a position would be deducted from X's compensation. Whether or not such retraining can reasonably be expected will depend on X's age; the older an injured person is, the less he can be expected to change his occupation. ${ }^{466}$ Damages for loss of earnings would be calculated on the basis of X's net income. X's 'retirement damage' would also be indemnified. ${ }^{467}$

190 In contrast, it is unlikely that the costs of the private medical injuries assessment commissioned by $\mathrm{X}$ would be compensated, as such assessment would not have been necessary in the instant case. However, this might depend on whether $\mathrm{X}$ had legal representation or not, for although a lawyer would be expected to know that the facts could be evaluated free of charge by a specific assessment commission, this might not necessarily apply to laypersons.

\footnotetext{
461 On the requirements for liability under art 55(1) CO, see supra, nos $48 \mathrm{ff}$.

462 See supra, nos $83 \mathrm{ff}$.

463 Cf supra, no 184 and (generally) no 90.

464 Cf supra, no 183.

465 On the requirements under art 41(1) CO, cf supra, no 47.

466 Cf Brehm (fn 97) art 44 no 51 with further references.

467 See supra, nos 110 and 116.
} 
Liability of A, B, C, and D would be joint and several (art 51 CO), ${ }^{468}$ both 191 with respect to X's pecuniary and non-pecuniary loss. ${ }^{469}$ Compensation for non-pecuniary loss would be available under art 47 CO. 470

\section{Case 6}

The following analysis is based on the assumption that A and B do not conduct their joint practice in the form of a company (with independent legal personality) by whom they are employed.

$A$ and $B$ might be liable toward $X$ in contract under art 97(1) CO.471 However, $\mathrm{X}$ will have to prove that $\mathrm{A}$ and $\mathrm{B}$ or their auxiliaries made a mistake which constitutes a breach of contract, and that such breach caused her damage. C, D, and E all qualify as auxiliaries under art 101(1) CO.472

As the transmission of E's staphylococcus infection caused $\mathrm{X}$ bodily harm, and as E is A and B's auxiliary, transmission as such could qualify as a breach of contract by A and B under art 101(1) CO. X would have no difficulty proving causation, as transmission was a conditio sine qua non of her damage. A and B could only avoid liability if they proved that $\mathrm{E}$ complied with the standard of care owed by A and B themselves, for which they bear the burden of proof. ${ }^{473}$ However, they are unlikely to succeed due to the deficient hygiene standards in their practice.

A and B's failure to maintain satisfactory hygiene standards also constitutes a breach of their contract with X. However, under this line of argument, $\mathrm{X}$ would have to prove that such failure more likely than not caused her damage. ${ }^{474}$ Whether or not $\mathrm{X}$ will be successful in proving causation will depend on how large the risk of infection would have been had the usual hygiene standards been maintained. It is not recognised in Swiss law that hospitals and responsible doctors bear the burden of proof with regard to causation in the case of deficient hygiene standards, although such a shift in the burden of proof has been suggested in legal doctrine. 475

468 On joint and several liability, see supra, no 66.

469 On the latter, see supra, no 129.

470 Cf supra, nos $125 \mathrm{ff}$.

471 On the requirements under art 97(1) CO, see supra, no 82.

472 On art 101(1) CO, see supra, no 85.

473 Cf supra, no 85.

474 Cf supra, no 56.

475 See Kuhn (fn 154) 601, 650 ff with further references. The Federal Court has not yet been called on to decide this issue. 
196 A further possibility would be to extend the notion of mistake in treatment by arguing that treatment administered under deficient hygiene standards is not lege artis. If this line of argument were accepted, the treatment administered by $\mathrm{C}$ and $\mathrm{D}$ (ie the injections) would already constitute a breach of A and B's contract with X under art 101(1) CO. X could prove causation as the breach was a conditio sine qua non of her damage. A and B would be unable to avoid liability as $\mathrm{C}$ and $\mathrm{D}$ did not comply with the standard of care owed by A and B themselves (hypothetical fault.) $)^{476}$

$197 X$ could also base her claim against A and B in tort under art 55(1) CO.477 As it is certain that E caused X's injury, and as E is subordinated to A and $\mathrm{B}, 478 \mathrm{~A}$ and $\mathrm{B}$ will only be able to avoid liability if they can show that they exercised all due diligence in selecting, instructing and overseeing $\mathrm{E}$. As it is established that the medical assistants were not instructed properly nor supervised with respect to hygiene, A and B will not succeed. Although A and B could avoid liability under art 55(1) CO by proving that X's damage would also have occurred if they had exercised due diligence,479 it will be practically impossible for them to provide such proof.

198 C and D could only be liable toward X in tort under art 41(1) CO.480 However, under orthodox rules of causation, $\mathrm{X}$ would have to prove whether it was $C$ or $D$ who administered the harmful injection. If she cannot provide such proof, neither $\mathrm{C}$ nor $\mathrm{D}$ will be held liable. ${ }^{481} \mathrm{X}$ would also have to prove that the doctor who gave the injection was at fault.

199 Although E caused X's damage, she could only become liable toward X under art 41(1) CO if X could prove that $E$ acted negligently. ${ }^{482}$ Such proof will only succeed if $X$ can show that $E$ knew or ought to have known of her staphylococcus infection and the associated risks.

200 Accordingly, A and B are likely to be liable toward X in contract and in tort. If $\mathrm{X}$ is unable to perform all of her household tasks because of her injury, she will be entitled to compensation on the basis of the average cost

\footnotetext{
476 Cf supra, no 85.

477 On the requirements for liability under art 55(1) CO, see supra, nos $48 \mathrm{ff}$.

478 Depending on how long C and D were working as locums in A and B's practice, it is possible that $\mathrm{E}$ might be considered to be subordinated to $\mathrm{C}$ and $\mathrm{D}$, rather than to $\mathrm{A}$ and B. In that case, A and B would not be liable toward X under art 55(1) CO. On the issue of de facto subordination, see supra, no 48.

479 Cf supra, no 50.

480 But cf fn 478. On the requirements under art 41(1) CO, cf supra, no 47.

481 On this issue of alternative causation, see supra, no 60.

482 Cf supra, no 54 .
} 
of home help, regardless of whether she actually employs such help or whether help is given free of charge. ${ }^{483} \mathrm{~A}$ and $\mathrm{B}$ will also be liable for nonpecuniary loss under art 47 CO. 484

\section{Variation 1}

Although the source of the infection cannot be identified, A and B will 201 nonetheless be liable toward $\mathrm{X}$ in contract if $\mathrm{X}$ can prove that she probably would not have suffered damage if A and B had maintained satisfactory hygiene standards. This will again depend on how large the risk of infection would have been had the usual hygiene standards been maintained. 485

As before, another possibility would be to extend the notion of mistake in treatment by arguing that treatment administered under deficient hygiene standards is not lege artis. In this case, A and B would be unable to avoid liability as $\mathrm{C}$ and $\mathrm{D}$ did not comply with the standard of care owed by $\mathrm{A}$ and $\mathrm{B}$ themselves. 486

In contrast, as the source of the infection cannot be identified, $\mathrm{X}$ cannot hold A and B liable under art 55(1) CO as she will be unable to prove that damage was caused by a subordinate. 487

As in the first scenario, $\mathrm{C}$ and $\mathrm{D}$ could only be liable toward $\mathrm{X}$ under art 41(1) CO if X succeeded in proving which doctor administered the harmful injection, and also that such doctor was at fault. ${ }^{488} \mathrm{E}$ will not be liable under art 41(1) CO as X is unable to prove that E caused her damage.

\section{Variation 2}

In this scenario, the only person who might be held liable toward X is E, 205 on the basis of art 41(1) CO. However, such claim will only succeed if X can prove that $\mathrm{E}$ acted negligently. 489

\footnotetext{
483 See supra, no 117.

484 On liability for non-pecuniary loss, cf supra, nos $124 \mathrm{ff}$.

485 See already supra, no 195.

486 Cf supra, no 196.

487 See supra, no 61.

488 See supra, no 198.

489 See already supra, no 199.
} 
Brought to you by | Universitaetsbibliothek Basel

Authenticated Download Date | 10/23/18 2:22 PM 